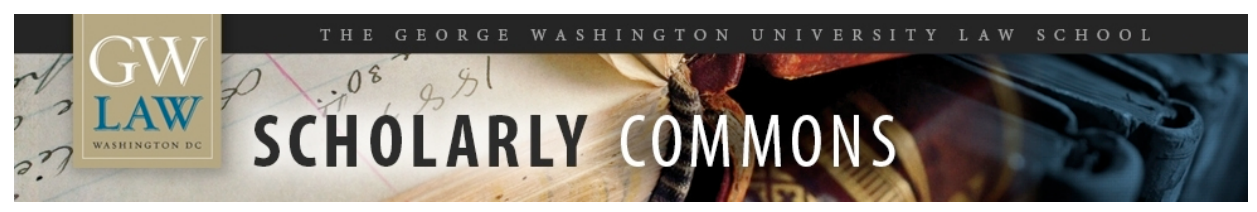

\title{
The Pandemic Crisis Shows that the World Remains Trapped in a 'Global Doom Loop' of Financial Instability, Rising Debt Levels, and Escalating Bailouts
}

Arthur E. Wilmarth Jr.

George Washington University Law School, awilmarth@law.gwu.edu

Follow this and additional works at: https://scholarship.law.gwu.edu/faculty_publications

Part of the Law Commons

\section{Recommended Citation}

40 Banking \& Financial Services Policy Report No. 8 (August 2021)

This Article is brought to you for free and open access by the Faculty Scholarship at Scholarly Commons. It has been accepted for inclusion in GW Law Faculty Publications \& Other Works by an authorized administrator of Scholarly Commons. For more information, please contact spagel@law.gwu.edu. 


\section{The Pandemic Crisis Shows that the World Remains Trapped in a "Global Doom Loop" of Financial Instability, Rising Debt Levels, and Escalating Bailouts}

Arthur E. Wilmarth, Jr.*

August 6, 2021

In January 2020, I completed a book analyzing the financial crises that precipitated the Great Depression of the 1930s and the recent Great Recession. My book argued that the world's financial system was caught in a "global doom loop" at the beginning of 2020. Bailouts and economic stimulus programs during and after the global financial crisis of 2007-09 (GFC) had imposed heavy debt burdens on most governments, and leading central banks were carrying bloated balance sheets. The rescues arranged by governments and central banks during the GFC created a widely-shared expectation that they would continue to intervene to ensure the stability of major financial institutions and important financial markets. That expectation encouraged speculative risk-taking by financial institutions and investors as well as dangerous growth in private and public debts. I warned that the global doom loop was planting the seeds for the "next" financial crisis, which could overwhelm the already strained resources of governments and central banks. ${ }^{1}$

The "next" global crisis began only two months later, in March 2020. The rapid spread of the Covid-19 pandemic caused governments in most developed countries to shut down large sectors of their economies and impose social distancing mandates. Many thousands of businesses closed, setting off a downward spiral in economic activity that paralyzed global financial markets. Investors, businesses, and financial institutions "scrambled for cash" and engaged in panicked "fire sales" of financial assets. Governments and central banks in the U.S.,

\footnotetext{
* Professor Emeritus of Law, George Washington University Law School (Washington, DC).

${ }^{1}$ Arthur E. Wilmarth, Jr., Taming the Megabanks: Why We Need a New Glass-Steagall Act, at 4-5, 12-14, 289-303, 316-27, 352-56 (Oxford Univ. Press, 2020) [hereinafter Wilmarth, Taming the Megabanks].
} 
United Kingdom (U.K.), European Union (EU), and other advanced economies adopted fiscal stimulus measures and financial rescue programs with a size, scope, and speed that far surpassed the emergency actions taken during the GFC.

The pandemic financial crisis and the extraordinary responses of governments and central banks demonstrate that policymakers have not addressed the root causes of the GFC. Major financial institutions and financial markets remain highly unstable. They continue to underwrite rapidly rising levels of private and public debts based on their shared expectation of future government bailouts. Governments and central banks have expanded their "safety nets" far beyond banks and now protect their entire financial systems, including short-term wholesale credit markets, systemically important nonbanks, and the corporate bond market. As a practical matter, governments and central banks have "bankified" their financial systems, thereby undermining market discipline, stimulating dangerous asset bubbles, and increasing social inequality.

Our financial system must be reformed so that it no longer promotes unsustainable booms, fueled by reckless growth in private debts, followed by destructive busts that require massive bailouts and vast increases in government debts. My recent book provides a blueprint for needed reforms, including a new Glass-Steagall Act. A new Glass-Steagall Act would break up financial giants by separating banks from the capital markets and by prohibiting nonbanks from financing their operations with functional substitutes for bank deposits. A new GlassSteagall Act would establish a financial system that is more stable, more competitive, and more responsive to the needs of consumers, communities, and business firms. Properly implemented, a new Glass-Steagall Act would provide the most direct and practical way to break the global doom loop and end the toxic boom-and-bust cycles of the past quarter century. 


\section{Analysis}

\section{Credit Booms and Bailouts Produced Rapid Increases in Private and Public Debts Before and After the Global Financial Crisis}

Massive credit booms occurred on both sides of the Atlantic during the two decades that preceded the GFC. In the U.S., private debts doubled from $\$ 10.4$ trillion to $\$ 20.4$ trillion between 1991 and 1999, and they doubled again to reach $\$ 41.6$ trillion in 2007. U.S. private debts as a percentage of U.S. gross domestic product (GDP) increased from 169\% in 1991 to $212 \%$ in 1999 and $288 \%$ in 2007. The peak of the U.S. credit boom in 2007 topped the previous record for private-sector debts (250\% of GDP) at the onset of the Great Depression in 1930-31. ${ }^{2}$

A credit surge of comparable magnitude occurred in the U.K. and several other European countries, including Ireland, Portugal, and Spain. U.K. private debts as a percentage of U.K. GDP skyrocketed from $90 \%$ in 1987 to $200 \%$ in 1999 and over $400 \%$ in 2007. In 2008, private debt levels exceeded 200\% of GDP in Ireland and Spain and 175\% of GDP in Portugal. The GFC had its most devastating impact in countries that experienced the largest credit booms. ${ }^{3}$

Two categories of financial institutions played central roles in promoting the Transatlantic credit boom of the 1990s and 2000s. Commercial banks became "universal banks" in the U.S. and Europe as policymakers authorized banks to engage in capital markets activities. Nonbank financial institutions - including securities broker-dealers, consumer finance companies, hedge funds, and private equity firms - became "shadow banks" as governments allowed them to finance their operations by issuing financial claims that were payable in practice at par (100\% of face value) either on demand or within a very short period. Those short-term financial claims - including money market funds, commercial paper, and securities repurchase

\footnotetext{
${ }^{2} I d$. at 6-9 (including Figure 0.3), 196-97.

${ }^{3} I d$. at 6-9 (including Figures $0.2 \&$ 0.3), 196-97, 228-30, 295-98.
} 
agreements (repos) - served as functional substitutes for bank deposits and became "shadow deposits."

Universal banks and shadow banks led the way in financing the explosive growth of subprime home mortgages and other risky consumer debts on both sides of the Atlantic. Both types of institutions bundled hazardous mortgages and consumer loans into asset-backed securities (ABS), which were sold as "safe" assets to investors around the world. Universal banks and shadow banks used the "financial alchemy" of securitization - with the help of highlycompensated credit ratings agencies - to transform high-risk loans into highly-rated ABS. Policymakers actively encouraged those developments because they viewed the expansion of consumer credit as the best way to support household spending at a time when many middleincome and lower-income families were experiencing stagnant or declining incomes. ${ }^{4}$

Government debts also expanded during the 1990s and early 2000s, albeit at a somewhat slower pace than private-sector debts. U.S. federal, state and local government debts increased from $\$ 4.9$ trillion in 1991 to $\$ 7.0$ trillion in 1999 and $\$ 12.2$ trillion in 2007. Total U.S. private and public debts reached $\$ 53.8$ trillion in 2007 , equal to $366 \%$ of U.S. GDP. On a global basis, government debts rose from $\$ 22$ trillion to $\$ 34$ trillion between 2000 and 2007. During the same period, worldwide private and public debts increased from $\$ 84$ trillion (225\% of global GDP) to \$167 trillion (275\% of global GDP). Consequently, both the U.S. and the rest of the world confronted an enormous debt overhang problem when the GFC began in 2007. Widespread

\footnotetext{
${ }^{4}$ Id. at 3-4, 150-63, 180-85, 192-97, 208-42, 263-64; see also Raghuram G. Rajan, Fault Lines: How Hidden Fractures Still Threaten the World's Economy (Princeton University Press, 2010), at 2-9 and Chapter 1.
} 
defaults by consumers, businesses, and financial institutions triggered systemic financial crises in the U.S., U.K., and Europe. ${ }^{5}$

Governments and central banks responded to the GFC with unprecedented levels of support for their economies and financial systems. Most developed countries adopted large fiscal stimulus programs, resulting in significant increases in government debt burdens. ${ }^{6}$ Many governments and central banks also supported their financial institutions and financial markets with emergency loans, capital infusions, asset purchases, and financial guarantees. In the U.S., the total outstanding amount of emergency assistance to financial institutions and markets peaked at almost $\$ 7$ trillion in early 2009. EU governments provided nearly $€ 5$ trillion of state aid to their financial institutions and markets, and the EU narrowly avoided a catastrophic sovereign debt crisis. $^{7}$

Four leading central banks - the Federal Reserve (Fed), the Bank of England (BoE), the Bank of Japan (BOJ), and the European Central Bank (ECB) - adopted ultra-low interest rate policies that resulted in near-zero or negative short-term interest rates. They also established “quantitative easing” (QE) programs that involved vast purchases of government bonds, mortgage-backed securities, and other assets. Ultra-low interest rates and QE programs pushed down short-term and longer-term interest rates for the debts of governments, households, businesses, and financial institutions, thereby reducing government budget deficits as well as borrowing and debt service costs for public and private obligors. The Fed's balance sheet grew from $\$ 900$ billion in August 2008 to $\$ 4.5$ trillion in December 2016. During the same period, the

\footnotetext{
${ }^{5}$ Wilmarth, Taming the Megabanks, supra note 1, at 196-97, 228-30, 245-98, 321-22 (including Figure 12.1); see also Institute for International Finance, Global Debt Monitor (April 6, 2020), at 2 [hereinafter April 2020 IIF Global Debt Monitor], https://www.iif.org/publications/global-debt-monitor.

${ }^{6}$ OECD Economic Outlook: The Effectiveness and Scope of Fiscal Stimulus: Interim Report (Mar. 2009), https://www.oecd.org/economy/outlook/42421337.pdf.

${ }^{7}$ Wilmarth, Taming the Megabanks, supra note 1, at 281-96; see also Adam Tooze, Crashed: How a Decade of Financial Crises Changed the World, Chapters 7-18 (Penguin 2018).
} 
combined balance sheets of the Fed, BoE, BoJ, and ECB expanded from $\$ 4$ trillion to $\$ 15$ trillion. As a percentage of home country GDP, the balance sheets of the four central banks increased from $6 \%$ to $23 \%$ in the U.S. and U.K., $14 \%$ to $34 \%$ in the Eurozone, and $20 \%$ to $88 \%$ in Japan. ${ }^{8}$

In 2009, the Group of 20 (G20) nations agreed on a series of reforms to their financial systems to address the causes of the GFC. The G20's reform agenda focused mainly on technical improvements in financial regulation, including stronger capital and liquidity requirements for banks. However, the G20 did not advocate fundamental changes to the precrisis structure of financial institutions and financial markets. Consequently, the G20 left in place the universal banks and shadow banks that financed the credit boom of the 2000s.

Moreover, the massive bailouts provided to universal banks and shadow banks during the GFC helped those institutions to become even larger and more dominant players in global financial markets after $2009 .^{9}$

Universal banks and shadow banks underwrote another major expansion of private and public debts between 2009 and 2019. Universal banks provided large amounts of credit to shadow banks, and both types of financial institutions relied on short-term funding from money market funds, commercial paper, and repos as well as longer-term financing from capital markets. The lax credit policies of universal banks and shadow banks allowed private debts owed by U.S. households, nonfinancial businesses, and financial institutions to reach new all-

\footnotetext{
${ }^{8}$ Id. at 293-97, 321-22; Atlantic Council, Global QE Tracker (Dec. 1, 2020) (“Cumulative Balance Sheets - Fed, BoJ, ECB, and BoE") [hereinafter Global QE Tracker], https://www.atlanticcouncil.org/blogs/econographics/global-qe-tracker/; Paolo Cavallino \& Fiorella De Fiore, "Central banks' response to Covid-19 in advanced economies," BIS Bulletin No. 21 (June 5, 2020), at 6 (Graph 3), https://www.bis.org/publ/bisbull21.pdf; Federal Reserve Bank of St. Louis, MO, "FRED Economic Data: [Federal Reserve] Assets: Total Assets" (Updated July 29, 2021) [hereinafter FRED Fed Balance Sheet Data], https://fred.stlouisfed.org/series/WALCL;

${ }^{9}$ Wilmarth, Taming the Megabanks, supra note 1, at 281-320.
} 
time records at the end of 2019. Public debts also set new records as federal, state, and local governments borrowed heavily to mitigate the economic impact of the Great Recession. U.S. private debts increased from $\$ 41.6$ trillion to $\$ 48.9$ trillion between 2007 and 2019 , while federal, state, and local government obligations more than doubled, rising from $\$ 12.1$ trillion to $\$ 26.3$ trillion. The total U.S. debt burden of $\$ 75.2$ trillion topped $350 \%$ of GDP in 2019, not far below its record level of $366 \%$ in $2007 .^{10}$

Global debt levels followed the same pattern of relentless growth after the GFC. Worldwide private and public debts expanded from \$167 trillion (275\% of global GDP) in 2007 to $\$ 253$ trillion (322\% of global GDP) in 2019. Worldwide government debts in 2019 reached their highest level as a percentage of global GDP since World War II. Leading central banks supported the rapid growth of global private and public debts by extending their QE asset purchase programs and enlarging their balance sheets. ${ }^{11}$

U.S. and international policymakers expressed growing concerns about those rising debt levels, especially in the case of nonfinancial business firms. At the end of 2019, a majority of outstanding U.S. and global corporate bonds were rated either at or below the lowest investment grade (BBB), as investors chose to buy riskier bonds with higher yields in a world of ultra-low interest rates. In addition, most non-investment-grade corporate bonds and leveraged loans to businesses contained very weak covenants that allowed high levels of corporate leverage and provided few protections to investors. Officials warned that mutual funds and other investment

\footnotetext{
${ }^{10}$ Id. at 320-21; see also Board of Governors of the Federal Reserve System, Financial Accounts of the United States (Z.1), First Quarter 2021 (June 10, 2021), at 9 (Tables D.3 \& F.2) [hereinafter 2021 Fed Flow of Funds Data], https://www.federalreserve.gov/releases/z1/20210610/z1.pdf.

${ }^{11}$ Wilmarth, Taming the Megabanks, supra note 1, at 321-22; April 2020 IIF Global Debt Monitor, supra note 5, at $2-3$.
} 
funds holding risky corporate debts would be exposed to large losses as well as potential "runs" by investors if a serious recession occurred. ${ }^{12}$

In 2017 and 2018, the Fed and some other central banks tried to "normalize" their monetary policies and to restrain the growth of debt by adopting a policy of "quantitative tightening" (QT). The Fed raised its short-term interest rate target seven times and reduced the size of its balance sheet from $\$ 4.5$ trillion to less than $\$ 4$ trillion. The BoE approved an increase in its short-term interest rate target, and the ECB stopped buying government bonds. Those moves by central banks toward a policy of QT frightened investors and caused a major sell-off of higher-risk assets in global financial markets during the fourth quarter of 2018.

The market turmoil in late 2018 alarmed the Fed and other central banks, and they abandoned their QT efforts. The Fed stopped raising interest rates in January 2019, and it approved three quarter-point reductions in its short-term interest rate target during the second half of 2019. The Fed also expanded its balance sheet by more than $\$ 400$ billion during the fall of 2019 by purchasing short-term Treasury bills and providing Treasury-backed repo loans. The Fed's decision to expand its balance sheet followed a sudden and unexpected liquidity squeeze in the Treasury repo market in September. The Fed effectively acted as "market maker of last resort" after its primary dealers - including the biggest U.S. universal banks - refused to act as lenders to many borrowers that wanted to roll over their repo loans. ${ }^{13}$

\footnotetext{
12 Board of Governors of the Federal Reserve System, Financial Stability Report 19-23, 38-39, 45 (Nov. 2019), https://www.federalreserve.gov/publications/files/financial-stability-report-20191115.pdf; "Corporate Bond Market Trends, Emerging Risks, and Monetary Policy," OECD Capital Markets Series (2020), https://www.oecd.org/corporate/ca/Corporate-Bond-Market-Trends-Emerging-Risks-Monetary-Policy.pdf; Financial Stability Oversight Council, 2019 Annual Report 3, 6, 14, 29-35, 90-92, 121 (Dec. 2019), https://home.treasury.gov/system/files/261/FSOC2019AnnualReport.pdf.

${ }^{13}$ Wilmarth, Taming the Megabanks, supra note 1, at 322-27, 354-55; see also Gara Afonso et al., "The Market Events of Mid-September 2019,” Federal Reserve Bank of N.Y. Staff Report No. 918 (Mar. 2020), https://www.newyorkfed.org/medialibrary/media/research/staff_reports/sr918.pdf; Sriya Anbil, Alyssa Anderson \& Zeynep Senyuz, “What Happened in Money Markets in September 2019?”, FEDS Notes (Feb, 27, 2020),
} 
The ECB and other central banks joined the Fed in easing their monetary policies during 2019. The dramatic "U-turn" by the Fed and other central banks in 2019 continued their decadelong policy of using "unconventional monetary policies in a world awash in debt" to prevent financial disruptions that might undermine the broader economy. ${ }^{14}$

As I argued in my recent book, "The coordinated easing of monetary policy by central banks in 2019 confirms that policymakers have not resolved the systemic problems in financial markets that led to the financial crisis of 2007-09. The same interlocking system of universal banks and shadow banks remains in place, and that system continues to inflate a global debt bubble comparable to the one that burst in 2007." I warned that "post-crisis regulatory and monetary policies have produced a fragile and volatile global financial system, which depends on continuous infusions of central bank liquidity to support universal banks, large shadow banks, and the capital markets." Those policies created a "global doom loop, in which governments, central banks, universal banks, shadow banks, and capital markets are locked together in a dangerous web of mutual dependence." I predicted that the global doom loop was "likely to trigger a future financial crisis that will be even more devastating than the last one." 15 The crisis that swept through global financial markets in March 2020 indicated that my diagnosis was correct.

https://www.federalreserve.gov/econres/notes/feds-notes/what-happened-in-money-markets-in-september-201920200227.htm.

${ }^{14}$ Wilmarth, Taming the Megabanks, supra note 1, at 323-24 (quoting Mohamed El-Erian).

${ }^{15} \mathrm{Id}$. at 324-27. 


\section{A Second Series of Huge Bailouts Occurred during the Pandemic Crisis, Resulting in Extremely High Levels of Private and Public Debts}

The Covid-19 pandemic was "the most devastating shock to hit the global economy since the Second World War." ${ }^{\text {16 }}$ Most developed countries responded to the pandemic with mandatory shutdowns and social distancing orders that forced thousands of businesses to close, thereby inflicting vast losses on business owners and employees. Despite unprecedented government stimulus programs and enormous infusions of central bank liquidity, global GDP declined by $3.4 \%$ in 2020 . Average GDP levels in advanced economies dropped by $4.7 \%$, including declines of $3.5 \%$ in the U.S., $9.9 \%$ in the U.K., $6.6 \%$ in the Eurozone, and $4.8 \%$ in Japan. Unemployment rates increased and labor participation rates dropped sharply. The U.S. lost 22 million jobs during March and April 2020, and the nation's unemployment rate rose to $14.7 \%$, the highest level recorded since the Great Depression. Minorities, employees of small businesses, and younger, less-educated, and lower-skilled workers suffered the most severe job losses. ${ }^{17}$

The rapid spread of the pandemic in February and March 2020 and government shutdown mandates set off a contagious financial panic, which paralyzed global financial markets. The S\&P 500 index fell by 34\% between February 19 and March 23, 2020, including the largest single-day decline (12\% on March 16) since the 1987 stock market crash. Average equity prices in other advanced economies also dropped by a third during the same period. Investors engaged in a "scramble for cash," including runs on money market funds and corporate bond funds.

\footnotetext{
${ }^{16}$ Bank for International Settlements, Annual Economic Report 2020, at 1 (June 2020) [hereinafter June 2020 BISAEO], https://www.bis.org/publ/arpdf/ar2020e.pdf.

${ }^{17}$ Id. at ix-xiv, 1-9; Bank for International Settlements, Annual Economic Report 2021, at 1-7 (June 2021) [hereinafter June 2021 BIS-AEO], https://www.bis.org/publ/arpdf/ar2021e.pdfInternational Monetary Fund, World Economic Outlook, at 1-9, 43-47 (April 2021), https://www.imf.org/en/Publications/WEO/Issues/2021/03/23/worldeconomic-outlook-april-2021; Board of Governors of the Federal Reserve System, Semiannual Monetary Policy Report 5-9, 24-26, 35-36 (June 12, 2020) [hereinafter 2020 Fed Monetary Policy Report], https://www.federalreserve.gov/monetarypolicy/files/20210709_mprfullreport.pdf;
} 
Markets froze for most government bonds and nearly all private debts, including commercial paper, repos, corporate bonds, and leveraged loans. Credit ratings agencies downgraded more than \$1 trillion of corporate bonds between March and May 2020, and credit spreads for higherrisk debt securities rose to their highest levels since 2008. Big universal banks were either unable or unwilling to act as dealers and market makers for a broad range of financial instruments, including repos, mortgage-backed securities, corporate bonds, and exchange-traded funds holding corporate debt. Many foreign banks and other foreign borrowers could not obtain funding in dollars to satisfy their dollar-denominated obligations. ${ }^{18}$

Market conditions stabilized only after governments and central banks around the world established a wide array of emergency facilities to support financial institutions and financial markets, supplemented by massive fiscal stimulus programs. The size, scope, and speed of governmental responses to the pandemic crisis far surpassed the emergency measures adopted during the GFC. Congress approved \$5.2 trillion of fiscal stimulus programs between March 2020 and March 2021 - a response that was four times as large as U.S. fiscal stimulus measures

\footnotetext{
${ }^{18}$ Sirio Aramonte \& Fernando Avalos, "The recent distress in corporate bonds markets: cues from ETFs," BIS Bulletin No. 6 (April 14, 2020), at 1-5 (quote at 3), https://www.bis.org/publ/bisbull06.pdf; June 2020 BIS-AEO, supra note 16, at 9-18 (including Graphs 1.7 \& 1.8), 39-47; 2020 Fed Monetary Policy Report, supra note 17, at 1618, 27-34, 37-41; Financial Stability Oversight Council, 2020 Annual Report 3-8, 13-29, 35-45, 99-106, 110-11, 117-20, 128-35, 167-69, 174-75, 178-79 (Dec. 2020) [hereinafter 2020 FSOC Annual Report], https://home.treasury.gov/system/files/261/FSOC2020AnnualReport.pdf; see also Craig A. Chikis \& Jonathan Goldberg, "Dealer Inventory Constraints in the Corporate Bond Market during the COVID Crisis," FEDS Notes (July 15, 2021) (showing that available liquidity for corporate bonds fell by more than $40 \%$ during the early stages of the pandemic crisis, due in part to significant reductions in bond inventories held by large bank dealers), https://www.federalreserve.gov/econres/notes/feds-notes/dealer-inventory-constraints-in-the-corporate-bondmarket-during-the-covid-crisis-20210715.htm; Ryan Clements, "Exchange-Traded Confusion: How Industry Practices Undermine Product Comparisons in Exchange-Traded Funds," 15:2 Virginia Law \& Business Review 121, 134-38 (2021) (discussing failures by large bank dealers to act as market makers ("account parties") in March 2020 after secondary market prices for bond ETFs dropped far below their designated net asset values); Justin Baer, "The Day Coronavirus Nearly Broke the Financial Markets," Wall Street Journal (May 20, 2020) (describing the systemic panic that occurred in financial markets on March 16, 2020, including refusals by big banks to act as dealers in markets for debt securities), https://www.wsj.com/articles/the-day-coronavirus-nearly-broke-the-financial-markets11589982288.
} 
during the Great Recession of 2007-09. ${ }^{19}$ During the same period, the U.S. and other governments around the world adopted pandemic stimulus programs totaling $\$ 16$ trillion, which provided "extraordinary support to the balance sheets of firms and households." 20

Central banks responded with emergency lending and guarantee programs that stabilized financial institutions and financial markets, thereby ensuring "market functioning and access to credit" and preventing "widespread financial turmoil." Many governments provided fiscal backstops to support the lending and guarantee programs of their central banks. Central banks also maintained ultra-low interest rates and purchased vast quantities of government bonds, mortgage-backed securities, and other assets "to reduce the costs of raising and servicing private and public debt." A high degree of coordination between governments and central banks meant that "fiscal and monetary policy supported each other in the pursuit of macroeconomic stability."21

Large-scale asset purchases by the Fed, BoE, BoJ, and ECB expanded their balance sheets from $\$ 15$ trillion to $\$ 25$ trillion between January 2020 and June 2021. During the same period, their balance sheets as a percentage of home country GDP increased from $19 \%$ to $34 \%$ for the Fed, $27 \%$ to $43 \%$ for the BoE, $38 \%$ to $61 \%$ for the ECB, and $104 \%$ to $131 \%$ for the BoJ. ${ }^{22}$

${ }^{19}$ Christina D. Romer, "The Fiscal Policy Response to the Pandemic" (Mar. 25, 2021), at 1-2, 8-15 \& Table 1, https://www.brookings.edu/wp-content/uploads/2021/03/BPEASP21_Romer_conf-draft_updated.pdf.

${ }^{20}$ Dario Caldara et al., "The Global Recovery: Lessons from the Past,” FEDS Notes (June 22, 2021) (quote), https://www.federalreserve.gov/econres/notes/feds-notes/the-global-recovery-lessons-from-the-past-20210622.htm; Kristalina Georgieva, "Giving People a Fair Shot - Policies to Secure the Recovery” (speech by IMF Managing Director on Mar. 30, 2021), https://www.imf.org/en/News/Articles/2021/03/25/sp033021-SMs2021-Curtain-Raiser; 2020 BIS-AEO, supra note 16, at 11-12, 22-29 \& Chapter II; 2020 Fed Monetary Policy Report, supra note 17, at 24, 19-22, 42-52.

${ }^{21}$ Caldara et al., supra note 20 (first two quotes); Cavallino \& De Fiore, supra note 8 (last two quotes); June 2020 BIS-AEO, supra note 16, at 22-23 \& Chapter II; Financial Stability Board, Global Monitoring Report on Non-Bank Financial Intermediation 2020, at 59-63, 67-75 (Dec. 16, 2020) [hereinafter 2020 FSB Shadow Banking Report], https://www.fsb.org/wp-content/uploads/P161220.pdf.

22 Ritvik Carvalho \& Tommy Wilkes, "Global liquidity is shrinking and that's no bad thing," Reuters (May 20, 2021), https://www.reuters.com/business/global-markets-cenbank-analysis-2021-05-20/; Cavallino \& De Fiore, 
Like other major central banks, the Fed quickly revived almost all of the crisis management tools it established during the GFC. The Fed approved a near-zero short-term interest rate target, provided emergency loans to banks and securities broker-dealers, and restored crisis-era programs that provided blanket guarantees for short-term wholesale financial markets (including money market funds, commercial paper, and repos) as well as markets for asset-backed securities. The Fed supercharged its QE program by pledging to buy unlimited amounts of Treasury bonds and federal agency mortgage-backed securities. The Fed's QE purchases expanded its balance sheet from $\$ 4.3$ trillion on March 11, 2020, to $\$ 7.2$ trillion on June 10, 2020, and $\$ 8.2$ trillion on July 14, 2021. The Fed also stabilized overseas dollar funding markets by opening swap lines with more than a dozen foreign central banks. ${ }^{23}$

In addition, the Fed established a series of novel lending programs, with supporting guarantees from the U.S. Treasury under the CARES Act. The Fed's new programs provided financing for (1) loans made by banks to small businesses under the Paycheck Protection Program, (2) loans made by banks to midsized businesses under the Main Street Lending Program, and (3) purchases of state and local government bonds under the Municipal Liquidity Facility. The Fed also established the Primary and Secondary Corporate Market Credit Facilities with the Treasury's backing. Those two programs authorized the Fed to buy investment-grade

supra note 8, at 6 (Graph 3); Global QE Tracker, supra note 8 ("Cumulative Balance Sheets" \&"Balance Sheets as a Percentage of GDP” graphs); Edward Yardeni \& Mali Quintana, Central Banks: Monthly Balance Sheets (July 23, 2021), at 1 (Figure 1) \& 3 (Figure 5), https://www.yardeni.com/pub/peacockfedecbassets.pdf.

${ }^{23}$ Board of Governors of the Federal Reserve System, Semiannual Monetary Policy Report 39-41, 46-47 (July 9, 2021) [hereinafter 2021 Fed Monetary Policy Report], https://www.federalreserve.gov/monetarypolicy/files/20210709 mprfullreport.pdf; 2020 Fed Monetary Policy Report, supra note 17, at 43-52; FRED Fed Balance Sheet Data, supra note 8; Jeffrey Cheng et al., "What's the Fed doing in response to the Covid-19 crisis? What more could it do?" (Mar. 30, 2021), https://www.brookings.edu/research/fed-response-to-covid19/; Marc Labonte, “The Federal Reserve's Response to COVID-19: Policy Issues,” Congressional Research Service (No. R46411, updated Feb. 8, 2021),

https://crsreports.congress.gov/product/pdf/R/R46411; Lev Menand, “The Federal Reserve and the 2020 Economic and Financial Crisis" (European Corporate Governance Institute - Law Working Paper No. 518/2020, May 2021), available at http://ssrn.com/abstract=3602740. 
and non-investment-grade corporate bonds - either directly from corporate issuers or in the secondary market - as well as bond ETFs. The Fed bought almost $\$ 14$ billion of corporate bonds and bond ETFs, and the Fed also financed more than $\$ 16$ billion of loans to midsized companies. In addition, the Fed pledged to buy up to $\$ 750$ billion of corporate bonds to stabilize the corporate bond market. ${ }^{24}$

The Fed's ultra-low interest rates and its unprecedented support for the corporate bond market "allow[ed] investment grade firms to issue new debt at historically low yields." 25 As one Wall Street insider explained, the Fed "essentially told the world that there is now a backstop on corporate debt ... . By directly intervening [in the corporate bond market, the Fed] has established a precedent that will be impossible to reverse. . . We have now socialized credit risk."26

The Fed's massive backstop for corporate debt enabled U.S. companies to issue \$2.5 trillion of bonds in 2020, "the largest [U.S.] corporate borrowing spree on record." U.S. nonfinancial business debts rose by more than $9 \%$ during 2020 and set a new record of $\$ 17.7$ trillion at the end of the year. Generous support programs for business loans in the U.S. and many other countries enabled corporations around the world to issue $\$ 5.35$ trillion of bonds in

\footnotetext{
${ }^{24}$ Michael Barr, Howell Jackson \& Margaret Tahyar, The Financial Response to the COVID-19 Pandemic 1-15 (Aug. 1, 2020), http://ssrn.com/abstract=3666461; Board of Governors of Federal Reserve System, Financial Stability Report 9-14, 32-34, 49-52 (Nov. 2020), https://www.federalreserve.gov/publications/files/financialstability-report-20201109.pdf; Cheng et al., supra note 23; Labonte, supra note 23; Menand, supra note 23; 2020 Fed Monetary Policy Report, supra note 17, at 19-22, 31-33, 43-52; 2020 FSOC Annual Report, supra note 18, at 15-24. 34-45, 99-106, 117-18, 128-30, 141-43.

252020 FSOC Annual Report, supra note 18, at 15-16.

${ }^{26}$ Christopher Leonard, "How Jay Powell's Coronavirus Response Is Changing the Fed Forever," Time (June 11, 2020) (quoting Scott Minerd, chief investment officer for Guggenheim Investments), https://time.com/5851870/federal-reserve-coronavirus/.
} 
2020, a "record borrowing binge." Global nonfinancial corporate debts increased by over $12 \%$ during 2020 and reached $\$ 85.2$ trillion at the end of the year. ${ }^{27}$

Government fiscal stimulus programs and central bank QE purchases also supported large increases in debt levels for governments, households, and financial institutions. In December 2020, government debts in the U.S. and worldwide climbed to their highest levels since World War II as a percentage of U.S. and global GDP. ${ }^{28}$ U.S. private and public debts increased by $10 \%$ to $\$ 82.7$ trillion during 2020 and reached 385\% of U.S. GDP - eclipsing the previous record of $366 \%$ in 2007. Similarly, global private and public debts rose by over $12 \%$ during 2020 and set a new record of $\$ 290.6$ trillion, equal to $359 \%$ of global GDP. ${ }^{29}$

Thus, governments and central banks took extraordinary steps to contain the financial and economic impact of the Covid-19 pandemic. Governments and central banks repeated and expanded their emergency responses to the GFC. Both crises demonstrated the willingness of

\footnotetext{
${ }^{27}$ Nikou Asgari \& Joe Rennison, "Corporate debt sales to shrivel in 2021 after record boom," Financial Times (Dec. 31, 2020) (second quote), https://www.ft.com/content/8ec279bf-fada-42ee-9a8e-86349a53efc8; Joe Rennison, "Fed backstop masks rising risks in America's corporate debt market," Financial Times (Dec. 22, 2020) (first quote), https://www.ft.com/content/7fa7e230-5a8f-4a65-b8b7-ecd603a2a3d1; see also 2021 Fed Flow of Funds Data, supra note 10, at 7 (Table D.3); Puneet Wadhwa, "Global debt rises $\$ 32$ trillion in 2020 amid Covid pandemic," Business Standard (June 8, 2021), https://www.business-standard.com/article/international/global-debtrises-32-trillion-in-2020-amid-covid-pandemic-moody-s-121060800412_1.html.

${ }^{28}$ U.S. federal, state, and local government debts totaled $\$ 30.9$ trillion in December 2020, equal to $144 \%$ of U.S. GDP. Global government debts totaled $\$ 83.4$ trillion, equal to $105 \%$ of global GDP. Both debt levels were the highest recorded since World War II. 2021 Fed Flow of Funds Data, supra note 10, at 7, 9 (Tables D.3 \& F.2); Federal Reserve Bank of St. Louis, MO, "FRED Economic Data, Federal Debt: Total Public Debt" (updated June 2, 2021) [hereinafter "FRED Federal Debt Data'], https://fred.stlouisfed.org/series/GFDEBTN; Wadhwa, supra note 27; Marcus Walker \& Peter Landers, "Governments World-Wide Gorge on Record Debt, Testing New Limits," Wall Street Journal (July 12, 2021), https://www.wsj.com/articles/governments-world-wide-gorge-onrecord-debttesting-new-limits-11626106592?st=7c59xoeftkt3xnw; see also Congressional Budget Office, "The 2021 LongTerm Budget Outlook" (Mar. 2021) [hereinafter 2021 CBO Budget Outlook], https://www.cbo.gov/publication/57038. ${ }^{29} 2021$ Fed Flow of Funds Data, supra note 10, at 7, 9 (Tables D.3 \& F.2); Federal Reserve Bank of St. Louis, FRED Economic Data, "Gross Domestic Product" (Updated July 29, 2021) [hereinafter FRED GDP Data], https://fred.stlouisfed.org/series/GDP; FRED Federal Debt Data, supra note 26; Wadhwa, supra note 27; Institute for International Finance, Global Debt Monitor (May 13, 2021) [hereinafter 2021 IIF Global Debt Monitor], https://iif.com/publications/global-debt-monitor.
} 
governments and central banks to adopt unprecedented and wide-ranging policies to stabilize financial institutions and financial markets and prevent a second Great Depression.

The colossal responses to the GFC and the pandemic crisis went far beyond the traditional "safety net" that governments and central banks previously provided to banks. From the 1950s through the early 1990s, governments and central banks in developed countries usually protected most depositors (especially retail depositors) and frequently rescued large banks that were considered "too big to fail" (TBTF). However, most governments and central banks during that period believed that nonbank financial institutions and business firms fell outside the "regulatory perimeter" and were not proper subjects for government bailouts or "lender of last resort" assistance from central banks.

Government "safety nets" expanded dramatically during both the GFC and the pandemic crisis. In addition to bailing out TBTF banks during the GFC, governments and central banks rescued short-term wholesale credit markets and systemically important shadow banks (including large securities broker-dealers and insurance companies) as well as a few big commercial enterprises (e.g., General Electric and General Motors). During 2020, governments and central banks went even further by protecting all of the financial institutions and markets they rescued in 2008 and by supporting the corporate bond market and many nonfinancial business firms. ${ }^{30}$

On July 28, 2021, the Fed took another fateful step by creating permanent "backstops in money markets" to ensure "smooth market functioning." The Fed established "standing" facilities that will offer repo loans (collateralized by Treasury or federal agency securities) to

\footnotetext{
${ }^{30}$ For discussions of changes in bailout policies between 1990 and 2020, see Cavallino \& De Fiore, supra note 8; June 2020 BIS-AEO, supra note 16, at 39-47; Labonte, supra note 23; William R. White, "Are changes in financial structure extending safety nets?" (BIS Working Paper No. 145, Jan. 2004), https://www.bis.org/publ/work145.pdf; Wilmarth, Taming the Megabanks, supra note 1, at 4-5, 152-53, 178-79, 254-98, 339-44; see also infra notes 65-67 and accompanying text.
} 
U.S. and foreign megabanks and foreign central banks. The Fed's new standing repo facilities received enthusiastic support from leading architects of the bailouts during the GFC, including Timothy Geithner, Lawrence Summers, and William Dudley. New York Fed President John Williams said the new facilities would "help calm markets in times of stress by giving financial firms confidence they will have easy access to liquidity.” The Fed's announcement of its new permanent "backstops" did not include any analysis of the potential future costs of providing "easy access to liquidity" for megabanks - including the costs of expanding their TBTF subsidies and increasing their incentives to take even greater risks at the public's expense. ${ }^{31}$

I have previously argued that governments and central banks "bankified" global financial markets in 2008 and 2020 by extending the traditional "safety net" for banks to rescue short-term wholesale credit markets, shadow banks, and the corporate bond market. ${ }^{32}$ The costs of "bankifying" financial markets have been immense, as governments are now saddled with huge debt burdens and central banks are weighed down by bloated balance sheets. As shown below, "bankifying" financial markets has greatly expanded the universe of financial claims that are supported by explicit and implicit government subsidies, and it has also entrenched the TBTF status of universal banks and large shadow banks.

\footnotetext{
${ }^{31}$ Board of Governors of the Federal Reserve System, "Press Release: Statement Regarding Repurchase Agreements" (July 28, 2021) (first three quotes), https://www.federalreserve.gov/newsevents/pressreleases/monetary20210728b.htm; Michael S. Derby, "Fed Launches Standing Repo Facility to Boost Market Liquidity," Wall Street Journal (July 28, 2021) (summarizing Mr. Williams' remarks), https://www.wsj.com/articles/fed-launches-standing-repo-facility-to-boost-market-liquidity11627496260?st=t27c552mhalaa04; Jonnelle Marte, "Fed establishes standing repo facilities to support money markets," Reuters (July 28, 2021), https://www.reuters.com/article/usa-fed-standing-repo/update-1-fed-establishesstanding-repo-facilities-to-support-money-markets-idUSL1N2P42C4; Colby Smith, "US Treasury market needs urgent reform, warn former policymakers," Financial Times (July 28, 2021), https://www.ft.com/content/5b417310f1b6-4f8a-af46-c55b65231ac4.

32 Art Wilmarth, "Why it would be a huge mistake to allow Big Tech firms to acquire banks," Fortune (Nov. 26, 2020), https://fortune.com/2020/11/26/big-tech-banking-glass-steagall-act-financial-crisis/.
} 


\section{Repeated Rescues of Shadow Deposit Markets Have Encouraged the Growth of Existing and New Types of Shadow Deposits}

In 2008 and 2020, governments and central banks bailed out money market funds, commercial paper, and repos as if they were bank deposits. Those bailouts fulfilled expectations by investors that "shadow deposits" - short-term financial instruments (STFIs) that are functional substitutes for bank deposits - would receive governmental support during financial crises to ensure repayment at par (100\% of face value). The bailouts of 2008 and 2020 have stimulated further growth in existing shadow deposit markets. They have also encouraged financial technology companies ("fintechs") to introduce new types of shadow deposits that create comparable systemic risks, including the likelihood of future government bailouts.

\section{a. The continued growth of existing types of shadow deposits}

Since the GFC, wholesale credit markets have generated rising volumes of STFIs that are functional substitutes for bank deposits. The largest categories of shadow deposits - money market funds, commercial paper, and repos - played central roles in the GFC, as investor runs on those instruments destabilized financial markets and caused the failures or near-failures of numerous large banks and shadow banks. ${ }^{33}$

"Prime" money market funds invest in STFIs issued by private-sector firms, including commercial paper, repos, and bank certificates of deposit (CDs). Prime money market funds offer to redeem shares held by retail investors at a fixed net asset value (NAV) equal to their purchase price of $\$ 1$ per share, thereby providing deposit-like treatment. "Government" money market funds invest in short-term government securities and redeem their shares at fixed NAVs for both retail and institutional investors.

\footnotetext{
${ }^{33}$ Wilmarth, Taming the Megabanks, supra note 1, at 254-56, 263-69, 276-98.
} 
Short-term commercial paper and repos provide repayment at par and offer the same appearance of immediate liquidity to institutional investors. Money market funds, commercial paper, and repos are shadow deposits because they compete with bank deposits as vehicles for short-term savings and liquidity. Shadow banks - including securities broker-dealers, private equity funds, hedge funds, and nonbank finance companies - rely on shadow deposits as sources of short-term funding to finance their longer-term loans and credit guarantees, which compete with the credit services of chartered banks. ${ }^{34}$

Money market funds are among the largest investors in bank CDs as well as commercial paper and repos. Money market funds are major sources of short-term funding for universal banks, shadow banks, and nonfinancial business firms. As a result, serious disruptions affecting money market funds are likely to destabilize the financial system and the general economy, as shown during the GFC and the pandemic crisis. ${ }^{35}$

The bailouts of 2008 and 2020 have encouraged the continued growth of shadow deposits and shadow banks by leading investors to expect that comparable bailouts will be provided during future financial disruptions. Assets held by global money market funds increased from \$5.5 trillion to $\$ 8.8$ trillion between 2008 and 2020, while global repo markets expanded from $\$ 6$

\footnotetext{
${ }^{34}$ For discussions of shadow deposits and shadow banks, see Jesse Eisinger, "This Bailout Is Working - for the Rich," ProPublica (May 10, 2020), https://www.propublica.org/article/the-bailout-is-working-for-the-rich; Financial Stability Board, Proposals to Enhance Money Market Fund Resilience: Consultation Report (June 30, 2021), at 710, 18-24 [hereinafter 2021 FSB Money Market Fund Report], https://www.fsb.org/wpcontent/uploads/P300621.pdf; 2020 FSB Shadow Banking Report, supra note 21; Jerry Marlatt, "Market Trends: 2020/21 Commercial Paper" Lexis-Nexis Practical Guidance (2021) (noting that 80\% of commercial paper issues have maturities of less than 21 days), available at https://www.mayerbrown.com/-/media/files/perspectivesevents/publications/2021/04/market-trends-202021_commercial-paper.pdf; Robin Kaiser-Schatzlein, "The 'Shadow Banks’ Are Back, and Still Too Big to Fail,’ New Republic (April 27, 2020), https://newrepublic.com/article/157455/shadow-banks-back-still-big-fail; Zoltan Pozsar et al., "Shadow Banking" (Fed. Res. Bank of NY Staff Report No. 458, July 2010), available at http://ssrn.com/abstract=1645337; Morgan Ricks, The Money Problem (2016); Wilmarth, Taming the Megabanks, supra note 1, at 153-57, 194, 263-64, 28188, 341-44.

352020 FSB Shadow Banking Report, supra note 21, at 68-75; 2021 FSB Money Market Fund Report, supra note 34, at 8-24; Wilmarth, Taming the Megabanks, supra note 1, at 153-57, 194, 255-56, 263-64, 281-86, 341-42.
} 
trillion to more than $\$ 11$ trillion. Approximately $\$ 1.7$ trillion of commercial paper was

outstanding in U.S. and European markets in early 2021, about the same level as in 2009. Total global assets held by shadow banks that issue short-term deposit substitutes and offer bank-like credit services have risen from $\$ 31.5$ trillion in 2008 to $\$ 57.1$ trillion in $2020 .{ }^{36}$

Investors are likely to run on money market funds during financial disruptions if fund managers cannot liquidate STFIs quickly to satisfy redemption demands. In 2008 and 2020, investor runs occurred at prime money market funds that held bank CDs, commercial paper, and repos. Markets for those STFIs froze, and many funds could not redeem their shares at their fixed NAVs. On both occasions, governments and central banks rescued money market funds and stabilized markets for STFIs. ${ }^{37}$

After the pandemic crisis subsided in the spring of 2021, big banks pressured many of their institutional customers to transfer funds from their bank deposit accounts into government money market funds sponsored by the banks. Big banks strongly encouraged those fund transfers because their sponsored money market funds do not have to satisfy the capital, liquidity, and deposit insurance requirements that apply to bank deposits. Government money market funds channeled much of their inflow of funds from bank deposits into reverse repurchase agreements with the Fed. ${ }^{38}$ In June 2021, the Fed increased the interest rate it pays on reverse repurchase agreements from zero to $0.05 \%$. The Fed raised that rate after mutual fund

\footnotetext{
362020 FSB Shadow Banking Report, supra note 21, at 18-19 \& Graph 1.7; id. at 27-57 (including 30-31 \& Table 3.1, 32-33 \& Graph 3.2, and 39-40 \& Graph 3.6); id. at 78 (Annex 2); 2021 FSB Money Market Fund Report, supra note 34, at 8-13 \& Figure 2; Marlatt, supra note 34.

${ }^{37}$ Eisinger, supra note 34; Kaiser-Schatzlein, supra note 34; 2020 FSB Shadow Banking Report, supra note 21, at 67-75; 2021 FSB Money Market Fund Report, supra note 34, at 11-24; Wilmarth, Taming the Megabanks, supra note 1 , at 3-4, 255-56. 263-64, 281-88, 341-42.

${ }^{38}$ Telis Demos, "Heard on the Street: A Pressure Valve Opens for Bank Stocks," Wall Street Journal (May 28, 2021), https://www.wsj.com/articles/a-pressure-valve-opens-for-bank-stocks-11622199601; Wenxin Du, "Money market funds: The tale of two diverging paths," Financial Times (June 24, 2021), https://www.ft.com/content/0983f29c-6aaa-48fb-be85-90780d8e5bda; see also 2021 Fed Monetary Policy Report, supra note 23 , at $29,33,46-47$.
} 
sponsors and investors lobbied the Fed to help government money market funds earn positive returns on their assets. ${ }^{39}$

Thus, despite recent proposals for reforms to address the continuing vulnerabilities of money market funds, big banks and the Fed have supported the continued growth of those funds. The motivations for big banks are obvious. Persuading customers to transfer their bank deposits into sponsored money market funds enables the banks to earn management fees from their funds while reducing their costs of complying with capital, liquidity, and deposit insurance requirements for deposits. However, it makes no sense for the Fed to support efforts by big banks to arbitrage prudential rules governing bank deposits. Nor is it wise for the Fed to encourage the continued growth of shadow deposits by providing "backstops" whenever a serious liquidity problem occurs.

I have proposed a simple and straightforward remedy to deal with the financial instability problems caused by shadow deposits. I would compel shadow deposits to become bank deposits by allowing only federally-insured depository institutions to issue financial instruments that are payable in practice at par either on demand or within 90 days from the date of their issuance. Prohibiting nonbanks from issuing short-term financial claims that are payable at par would dramatically shrink the shadow banking system. Shadow banks could no longer offer depositlike treatment to investors, and they would be compelled to fund their operations with equity securities or debt obligations that have maturities longer than 90 days. Equity securities and

\footnotetext{
${ }^{39}$ Colby Smith, "Investors rush to stash cash with Fed after interest rate tweak," Financial Times (June 17, 2021), https://www.ft.com/content/f0ec2136-5c68-489f-a851-83b12f3480b4; see also Michael Mackenzie \& Colby Smith, "Fed urged to aid money market funds as negative rates loom," Financial Times (June 15, 2021), https://www.ft.com/content/1c3ec473-e08f-4057-87ec-dcfa0f784521.
} 
longer-term debt obligations issued by nonbanks would be subject to a much higher degree of market scrutiny and a much lower risk of investor runs. ${ }^{40}$

My proposal would stop financial institutions and investors from evading deposit insurance rules, bank capital and liquidity standards, and bank reserve requirements by shifting their funds from bank deposits into lightly-regulated shadow deposits. My proposal would greatly enhance the ability of bank regulators to monitor and regulate the risks of short-term financial claims that are payable at par, as those instruments would have to be issued by federally-insured depository institutions that are subject to close supervision. ${ }^{41}$

My proposed prohibition against shadow deposits would require all money market funds that are not issued by federally-insured banks to redeem their shares based on floating NAVs, as other mutual funds must do. In the absence of deposit-like treatment, most investors would probably convert their money market funds into bank deposits. The Financial Stability Board recently acknowledged that prohibiting fixed NAVs for money market funds "would enhance financial stability, although funding sources for borrowers would become less diverse and more costly."${ }^{24}$ In view of the enormous costs and market-distorting effects of the 2008 and 2020 bailouts, removing fixed NAVs from money market funds issued by nonbanks would certainly not be "more costly" for society.

\section{b. New types of shadow deposits created by fintechs}

The dangers posed by shadow deposits have become even greater during the past several years, as fintechs have created novel types of deposit substitutes. For example, PayPal and its

\footnotetext{
${ }^{40}$ Wilmarth, Taming the Megabanks, supra note 1, at 13-14, 341-44, 355-56; see also Ricks, supra note 34 (presenting a similar proposal).

${ }^{41}$ Wilmarth, Taming the Megabanks, supra note 1, at 13-14, 341-44, 355-56; see also Ricks, supra note 34.

422021 FSB Money Market Fund Report, supra note 34, at 25-28, 36 (quote) (emphasis added); see also Wilmarth, Taming the Megabanks, supra note 1, at 341-44, 355-56.
} 
subsidiary Venmo are state-licensed money transmitters that provide payments services to almost 400 million accounts held by consumers and merchants. At the end of 2020, PayPal's organization (including Venmo) held $\$ 33$ billion of customer balances, compared with $\$ 10$ billion in 2014 and $\$ 22$ billion in 2019. PayPal's customers can withdraw balances held in their accounts on demand and can also transfer those balances to third parties. ${ }^{43}$ PayPal acknowledges that customer balances are unsecured liabilities of PayPal and are not protected by federal deposit insurance because PayPal is not a chartered bank. ${ }^{44}$

PayPal's customer balances are functionally equivalent to bank checking deposits, given its customers' ability to withdraw their balances on demand and to transfer their balances to third parties. Courts could reasonably determine that PayPal is unlawfully engaged in "the business of receiving deposits" in violation of Section 21(a)(2) of the Glass-Steagall Act. Section 21(a)(2) prohibits every person other than a regulated and supervised U.S. depository institution from "engag[ing], to any extent whatsoever . . . in the business of receiving deposits subject to check

\footnotetext{
${ }^{43}$ PayPal Holdings Inc., Form 10-K Annual Report for the fiscal year ended Dec. 31, 2020 [hereinafter 2020 PayPal 10-K Report], at 4-9, 35, 53, 59, 66, 70, 86 ("We offer our customers the flexibility to use their accounts to purchase and receive payments for goods and services, as well as the ability to transfer and withdraw funds.... We generally do not charge customers to fund or draw from their accounts.... We provide consumers with a digital wallet that enables them to send payments to merchants more safely using a variety of funding sources, which may include ... a PayPal Cash or Cash Plus account balance, [or] a Venmo account balance," id. at 4, 5, 7), available at https://d18rn0p25nwr6d.cloudfront.net/CIK-0001633917/649f6b82-3897-4940-b9f3-64c0937779aa.pdf. ${ }^{44}$ See PayPal website, "Manage your money, anytime, anywhere" (note 1) (visited on August 3, 2021) ("PayPal is not a bank and does not itself take deposits. You will not receive any interest on the funds in your PayPal Cash Plus account. Funds you hold in a PayPal Cash Plus account are not insured by the FDIC unless you have successfully requested a PayPal Cash Card," which is issued by The Bancorp Bank, an independent bank that offers Mastercard credit cards to PayPal customers), available at https://www.paypal.com/us/webapps/mpp/money-management; 2020 PayPal 10-K Report, supra note 43, at 70 ("We hold all customer balances, both in the U.S. and internationally, as direct claims against us which are reflected on our consolidated balance sheets as a liability classified as amounts due to customers"); see also David Bergenthal, "Your PayPal balance isn't FDIC-insured," Medium (Sept. 21, 2014), https://medium.com/@ dbrgndl/paypal-isnt-fdic-insured-non-banks-being-bankish-and-a-new-model-forfinancial-startups-df6d16c2d4b; Izabella Kaminska, "Is it a bank, a money transmitter, or a shadow Silicon Valley financier? No, it's just PayPal!", Financial Times (Aug. 6, 2015) ("PayPal accounts are no longer FDIC guaranteed because they don't sit in the regulated banking system, but exist as unsecured claims against PayPal, a money transmitter"), https://www.ft.com/content/455e3cd7-4eec-3c0e-ad77-ed602f6d9878.
} 
or to repayment upon ... request of the depositor." "45 In view of Section 21(a)(2)’s prohibition,

PayPal - a nonbank money transmitter - is operating in dangerous territory by accepting and

holding tens of billions of dollars of customer funds that can be withdrawn on demand or

transferred to third parties.

PayPal stands on equally shaky ground in terms of financial stability. In December 2020,

PayPal held reserves consisting of $\$ 17.7$ billion of short-term investments and $\$ 2.8$ billion of

long-term investments to back up its $\$ 33$ billion of customer balances. "Corporate debt

securities" accounted for $\$ 7.2$ billion of PayPal's reserves, and “[f]oreign government and

agency securities" represented another $\$ 2.8$ billion of reserves. ${ }^{46}$ Given the amount and nature of

its reserves, PayPal would face a very severe liquidity crisis if most of its customers insisted on

\begin{abstract}
4512 U.S.C. $\$ 378(a)(2)$; see Wilmarth, Taming the Megabanks, supra note 1, at 137-39, 153-54, 341, 410 (notes 36 \& 37) (discussing the terms and historical background of Section 21 of the Glass-Steagall Act); United States v. Jenkins, 943 F.2d 167, 174 (affirming the defendant's criminal conviction for violating Section 21(a)(2) because the defendant (an individual) "took custody" of $\$ 150,000$ on behalf of a purported foreign bank and "agreed to return it at the will" of the depositor, stating "[y]our money will be here for your use"); In re Thraxton Group, Inc., Securities Litigation, 2006 WL 8463540, at *1-*3, *9-*11,*13-*14 (D.S.C., Mar. 20, 2006) (holding that a nonbank firm violated Section 21(a)(2) by selling $\$ 121$ million of demand notes to 5,000 investors because the nonbank "engaged in the business of taking money from investors in return for a promise to return the funds on demand," and the "notes were designed to imitate bank certificates of deposit and money market accounts in order to attract bank depositors to the note program"); see also S \& N Equipment Co. v. Casa Grande Cotton Finance Co., 97 F.3d 337, 340-41, 343-45 (9th Cir. 1996) (concluding that a nonbank finance company accepted "demand deposits" for purposes of the Bank Holding Company Act because the finance company "accepted funds from its customers," placed those funds in "credit accounts," and allowed customers to "withdraw funds as needed" and transfer funds to third parties).
\end{abstract}

Howell Jackson and Morgan Ricks have called on federal agencies to clarify the "requirements for supervision and regulation" that institutions must satisfy to accept "deposits" under Section 21(a)(2). They have also suggested that companies like PayPal, which are state-regulated money transmitters and are also regulated by FinCen for compliance with money laundering laws, might qualify as institutions that can accept "deposits" under Section 21(a)(2). Howell E. Jackson \& Morgan Ricks, "Locating Stablecoins within the Regulatory Perimeter," Harvard Law School Forum on Corporate Governance (Aug. 5, 2021) (note 13), https://corpgov.law.harvard.edu/2021/08/05/locating-stablecoins-within-the-regulatory-perimeter/. I respectfully disagree with that suggestion. PayPal's current regulatory regime is not equivalent to bank regulation and supervision in any meaningful sense, and it therefore does not comport with the statutory terms and purpose of Section 21(a)(2). PayPal's regulatory regime is plainly inadequate to prevent PayPal from creating unacceptable risks to financial stability by issuing large volumes of run-prone, short-term financial claims that promise depositlike treatment but are subject to severe liquidity risks. To avoid any room for doubt, Congress should amend Section 21(a)(2) to make clear that only federally-insured depository institutions are allowed to accept "deposits." ${ }^{46} 2020$ PayPal 10-K Report, supra note 43, at 4-13, 53-54, 59, 67-68, 70, 86 (quotes). 
withdrawing their balances quickly. In February 2020, Fed Governor Lael Brainard warned that the "nonbank money" sitting in PayPal's customer balances was "not insured directly by the FDIC, and consumers may be at risk that the issuer will not be able to honor its liabilities." 47

Fintechs have produced another new category of shadow deposits called "stablecoins." A stablecoin is a cryptocurrency that purports to have a "stable" value because it is "backed" by sovereign currencies or other financial assets that appear to have a high degree of safety and liquidity. Stablecoins are the leading form of payment for trades executed on cryptocurrency exchanges. Traders in cryptocurrencies view stablecoins as "a vital tool, because of the speed with which [stablecoins] can be used to move money from one crypto exchange to another, and because they provide a handy way to park cash temporarily." 48 Stablecoins are "a central part of cryptocurrency trading in a similar way [that] money market funds are used by typical investors."49

The two most widely-used stablecoins are Tether (used in almost half of the $\$ 1$ trillion of stablecoin transactions completed during the first quarter of 2021) and USD Coin (used in more than a quarter of those transactions). Tether was launched in 2014, while USD Coin and eight other widely-used stablecoins were started in 2018 or later. Four-fifths of the stablecoins launched before 2016 later collapsed, as have a quarter of stablecoins that began to operate in $2018 .^{50}$

\footnotetext{
${ }^{47}$ Remarks by Fed Governor Lael Brainard, "The Digitalization of Payments and Currency: Some Issues for Consideration" (Feb. 5, 2020), https://www.federalreserve.gov/newsevents/speech/files/brainard20200205a.pdf.

${ }^{48}$ James Mackintosh, "Bitcoin's Reliance on Stablecoins Harks Back to the Wild West of Finance," Wall Street Journal (May 27, 2021), https://www.wsj.com/articles/bitcoins-reliance-on-stablecoins-harks-back-to-the-wildwest-of-finance-11622115246.

${ }^{49}$ Siddharth Venkataramakrishnan, "Stablecoin strife: crypto assets face calls for tougher oversight," Financial Times (May 13, 2021) [hereinafter "Stablecoin strife"], https://www.ft.com/content/e4081366-b061-4b17-bdbee975fcf6288d.

${ }^{50}$ Bruce Mizrach, "Stablecoins: Survivorship, Transactions Costs and Exchange Microstructure" (April 2021), http://ssrn.com/abstract=3835219; see also Mitsutoshi Adachi et al., "A regulatory and financial stability perspective on global stablecoins" (European Central Bank Research Brief, May 2020),
} 
The amount of outstanding stablecoins has grown rapidly and currently exceeds $\$ 110$ billion, due to surging trading volumes on cryptocurrency exchanges. The declared value of Tethers in circulation rose from $\$ 4$ billion in December 2019 to $\$ 20$ billion a year later and $\$ 63$ billion in June 2021. The stated value of USD Coins in circulation increased from $\$ 1$ billion in June 2020 to more than $\$ 25$ billion a year later. ${ }^{51}$ Stablecoins provide "a key source of liquidity in the crypto markets," but there are serious questions about their "associated risks, primarily revolving around the composition of the reserves backing them." 52

Tether, the largest stablecoin, has become "the de facto reserve currency of the global crypto economy" because it serves as a "dollar-like token of exchange, without the hassle and the risks of using real dollars.” The same executives who own Tether also control Bitfinex, a leading cryptocurrency exchange and a "key venue" for "price discovery" in crypto markets. ${ }^{53}$ Tether and Bitfinex are both incorporated in the "famously opaque British Virgin Islands." recent academic study concluded that top officials of Bitfinex issued large volumes of Tether tokens without reserves between March 2017 and March 2018 and used those tokens to boost Bitcoin's price by purchasing Bitcoins on Bitfinex and other cryptocurrency exchanges. ${ }^{55}$

https://www.ecb.europa.eu/pub/financial-stability/macroprudentialbulletin/html/ecb.mpbu202005_1 3e9ac10eb1.en.html\#toc1.

${ }^{51}$ Dave Michaels \& Alexander Osipovich, "SEC Chief Gary Gensler Braces for Clash With Crypto Traders," Wall Street Journal (Aug. 5, 2021), https://www.wsj.com/articles/sec-chief-gary-gensler-braces-for-clash-with-cryptotraders-11628164980; "Stablecoin strife," supra note 49; Siddharth Venkataramakrishnan, "Stablecoins must face 'difficult questions,' warns Bank of England," Financial Times (June 7, 2021) [hereinafter "Stablecoins questions"], https://www.ft.com/content/5bbf8546-29e4-4f7c-a30e-f15a5e261819; "Stablecoins: Bitcoin for squares has its own downsides," Financial Times (June 2, 2021) [hereinafter "Stablecoins downsides"],

https://www.ft.com/content/223a7391-84af-444e-8fbf-c61e1e0cdac6; Paul Vigna, Cryptocurrency Operator Circle to Go Public in \$4.5 Billion SPAC Merger," Wall Street Journal (July 8, 2021), https://www.wsj.com/articles/cryptocurrency-operator-circle-to-go-public-in-4-5-billion-spac-merger-11625754758. 52 Vigna, supra note 51; see also Michaels \& Osipovich, supra note 51.

${ }^{53}$ Kadhim Shubber \& Siddharth Venkataramakrishnan, "Tether: the former plastic surgeon behind the crypto reserve currency," Financial Times (July 16, 2021), https://www.ft.com/content/4da3060c-8e1a-439f-a1d7a6a4688ad6ca.

${ }^{54}$ Izabella Kaminska, "We all become MF Global eventually, Tether edition," Financial Times (April 26, 2019), https://www.ft.com/content/75daa4c5-8d26-35e9-bd3e-21e8430a3068.

55 John M. Griffin \& Amin Shams, “Is Bitcoin Really Untethered?”, 75:4 Journal of Finance 1913-64 (2020). 
Tether originally claimed that "[e]very tether is always backed 1-to-1, by traditional [dollar] currency held in our reserves.” Tether abandoned that claim in March 2019 and instead stated that its stablecoins were "always 100 percent backed by our reserves, which include traditional currency and cash equivalents and, from time to time, may include other assets and receivables from loans made by Tether to third parties, which may include affiliated entities." 56

New York Attorney General (NYAG) Letitia James filed an antifraud lawsuit against Tether and Bitfinex in April 2019. NYAG James alleged that Tether misrepresented the amount and nature of its reserves and also concealed the loss of $\$ 850$ million of customer funds caused by the malfeasance of a third-party payment processor. In February 2021, Tether and Bitfinex entered into a settlement agreement with NYAG James. Tether and Bitfinex agreed to pay a fine of $\$ 18.5$ million, to publish quarterly reports for two years about Tether's reserves, and to stop trading with New York residents. ${ }^{57}$

In May 2021, Tether published its first required quarterly report about its reserves. According to that report, only a quarter of Tether's reserves consisted of cash, cash equivalents, and short-term deposits on March 31, 2021. Commercial paper accounted for half of Tether's reserves, and most of its remaining reserves were secured loans and corporate bonds. As one analyst observed, "Tether's [reserve] assets are made up mainly of long and short-term corporate

\footnotetext{
${ }^{56}$ Kaminska, supra note 54 (quoting Tether's statements about its reserves) (emphasis added); Mizrach, supra note 50, at 2-3 (same).

${ }^{57}$ Paul Vigna, "Cryptocurrency Firms Bitfinex, Tether Settle New York Attorney General's Probe," Wall Street Journal (Feb. 23, 2021), https://www.wsj.com/articles/cryptocurrency-firms-bitfinex-tether-settle-new-yorkattorney-generals-probe-11614093709; see also Kaminska, supra note 54 (discussing the NYAG's lawsuit); Mizrach, supra note 50, at 2-3 (same). A copy of the settlement agreement signed by NYAG James, Bitfinex, and Tether is available at https://ag.ny.gov/sites/default/files/2021.02.17___settlement_agreement__execution_version.b-t_signed-c2_oag_signed.pdf.
} 
debt. . . . And we have no idea of who the borrowers are, except that long-term loans are not made to Tether's 'affiliates'., 58

USD Coin, the second largest stablecoin, followed Tether's example by abandoning its earlier claim that all of its outstanding tokens were backed by federally-insured deposit accounts at U.S. depository institutions. Since April 2020, Circle (the issuer of USD Coins) has published reports stating that USD Coins are backed by "total balances in accounts held by the Company at federally insured US depository institutions and in approved investments." ${ }^{59}$ In May 2021, Circle said its "approved investments" included "cash, cash equivalents, and short-duration investment-grade assets," but Circle did not provide further details about those assets. ${ }^{60}$ It therefore appears that Circle's reserves for USD Coins, like Tether's reserves, include significant amounts of commercial paper and other private-sector debt obligations.

Fed Governor Lael Brainard has warned that stablecoins pose "consumer protection and financial stability risks because of their potential volatility and the risk of run-like behavior." Many analysts believe that a run by investors on leading stablecoins like Tether and USD Coin would threaten the viability of cryptocurrency markets, as stablecoins are the primary method of settling trades on those markets. In addition, Securities and Exchange Commission Chair Gary Gensler has criticized stablecoins for enabling traders in cryptocurrencies "to sidestep a host of

\footnotetext{
${ }^{58}$ Jemima Kelly, "Tether says its reserves are backed by cash to the tune of . . 2.9\%," Financial Times (May 14, 2021) (quoting Frances Coppolla) (emphasis in original), https://www.ft.com/content/529eb4e6-796a-4e81-80645967bbe3b4d9; see also "Stablecoins downsides," supra note 51.

${ }^{59}$ See "Reserve Account Reports" issued by Circle Internet Financial LLC, dated March 13, 2020, April 13, 2020 (emphasis added), and June 9, 2021 (emphasis added), each with a supporting "opinion" from Grant Thornton LLP, available at https://www.centre.io/hubfs/pdfs/attestation/grant-thornton_circle_usdc_reserves_20200313.pdf (report of March 13, 2020); https://www.centre.io/hubfs/pdfs/attestation/grantthornton_circle usdc reserves 20200413.pdf (report of April 13, 2020); and https://f.hubspotusercontent00.net/hubfs/6778953/USDCAttestationReports/2021-Circle-internet-financialattestation-april-2021.pdf (report of June 9, 2021). See also Siddarth Venkataramakrishnan, "Circle listing will test top stablecoin's transparency over reserves," Financial Times (July 9, 2021) [hereinafter "Circle reserves"], https://www.ft.com/content/7676451f-23a9-42eb-a179-c3ebbcfc0bff.

60 "Circle reserves," supra note 59 (quoting Circle's statement).
} 
public policy goals connected to our traditional banking and financial system: anti-money laundering, tax compliance, sanctions, and the like." 61

Prime money market funds, PayPal's customer balances, and stablecoins are highly unstable and run-prone shadow deposits. Their customers are encouraged to believe that they are purchasing safe and "stable" substitutes for FDIC-insured bank deposits. In sharp contrast to federally-insured bank deposits, all three types of shadow deposits are "private money" that is not backed by the full faith and credit of any sovereign. Their reserves consist primarily of private-sector debt obligations that are likely to become illiquid and unsaleable (except at steeply discounted prices) during financial disruptions.

Boston Fed President Eric Rosengren highlighted the dangerous similarities between stablecoins and prime money market funds during an interview with Brian Cheung of Yahoo Finance in June 2021. Rosengren said that Tether's "portfolio" of reserves "looks like a portfolio of a prime money market fund but maybe riskier." Rosengren emphasized that "it's not just money market funds that we have to be worried about," and he warned that the "exponential growth in stablecoin" could "destabilize short term credit markets." 62

Cheung commented that "the Fed did step in during the midst of this pandemic to backstop the corporate debt market and commercial paper markets," and he therefore asked whether "the financial stability risk of those stablecoins like tether is only as big . . as the Fed will allow given its historical role as a back stopper?" Rosengren responded by stating his hope

\footnotetext{
${ }^{61}$ Remarks by Fed Governor Lael Brainard, "Private Money and Central Bank Money as Payments Go Digital: An Update on CBDCs" (May 24, 2021), https://www.federalreserve.gov/newsevents/speech/files/brainard20210524a.pdf; Remarks Before the Aspen Security Forum by SEC Chair Gary Gensler (Aug. 3, 2021), https://www.sec.gov/news/public-statement/gensleraspen-security-forum-2021-08-03; see also "Circle reserves," supra note 59; Kaminska, supra note 54; Kelly, supra note 58; Mackintosh, supra note 47; "Stablecoins questions," supra note 51; "Stablecoin strife," supra note 49.

${ }^{62}$ Brian Cheung, "Boston Fed President Rosengren Speaks with Yahoo Finance [Transcript]," Yahoo Finance (June 25, 2021), https://finance.yahoo.com/news/boston-fed-president-eric-rosengren-yahoo-finance-transcript-june-2021194630532.html.
} 
that "we would change the regulations so that the next time we have a crisis, we don't have to do it again."

Cheung's question and Rosengren's response underscored the severe financial instability risks and market distortions created by money market funds, stablecoins, and other shadow deposits. Cheung's question reflected the general expectation among financial institutions and investors that the Fed would continue to "backstop" shadow deposits to prevent destabilizing runs by holders of those instruments. Rosengren's answer signaled his awareness that further bailouts of shadow deposits would harm the public interest by further eroding market discipline and distorting prices in short-term wholesale credit markets.

In December 2020, three members of Congress introduced a bill called the "STABLE Act." The STABLE Act would prohibit the issuance of stablecoins by any person other than FDIC-insured depository institutions. It would also require FDIC-insured institutions to obtain prior regulatory approval before issuing stablecoins. Howell Jackson and Morgan Ricks have proposed that stablecoins should be treated as "deposits" under Section 21(a)(2) of the GlassSteagall Act, thereby prohibiting the issuance of stablecoins by entities other than regulated depository institutions. ${ }^{64}$ To ensure the stability of our financial system, Congress should amend Section 21(a)(2) to make clear that only federally-insured depository institutions are authorized to issue money market funds, stablecoins, and other short-term financial claims that are functionally equivalent to bank deposits.

\footnotetext{
${ }^{63} I d$.

${ }^{64}$ Press Release, “Tlaib, Garcia, and Lynch Introduce Legislation Protecting Consumers Against CryptocurrencyRelated Financial Threats" (Dec. 2, 2020) (describing the STABLE Act, introduced by Representatives Rashida Tlaib (D-MI), Jesús “Chuy” Garcia (D-IL), and Stephen Lynch (D-MA)), https://tlaib.house.gov/media/pressreleases/tlaib-garcia-and-lynch-stableact; Jackson \& Morgan, supra note 45.
} 


\section{Bailouts during the GFC and the pandemic crisis have confirmed the TBTF status of universal banks and large shadow banks}

During the GFC, the U.S., the U.K., and other European nations arranged enormous bailouts of large universal banks and systemically important shadow banks (including securities broker-dealers and insurance companies). In November 2009, Fed Chair Ben Bernanke told the Financial Crisis Inquiry Commission (FCIC) that all of the thirteen largest U.S. financial institutions except one (presumably JPMorgan Chase) would probably have failed during the GFC without the financial assistance they received from federal agencies. A month later, New York Fed President Timothy Geithner told the FCIC that "none of [the biggest banks] would have survived a situation in which we had let that fire try to burn itself out." Lehman Brothers and Washington Mutual were the only U.S. financial firms with over $\$ 100$ billion of assets that collapsed into bankruptcy during the GFC. The federal government's bailouts ensured that there would be "no more Lehmans or WaMus" after the end of September $2008 .{ }^{65}$

Similarly, the U.K. and other EU governments provided financial aid to more than 110 banks - including 12 of the 20 largest EU banks - and over 100 nonbank financial institutions. ${ }^{66}$ The rescues arranged by the U.S., U.K., and other EU governments fulfilled a pledge made by finance ministers of the Group of 7 nations (G7) on October 10, 2008. The G7 ministers stated

\footnotetext{
${ }^{65}$ Wilmarth, Taming the Megabanks, supra note 1, at 265-95; see also id. at 289, 457 (note 138) (citing and quoting Bernanke's and Geithner's statements during their FCIC interviews); id. at 290 (quoting Geithner's comment that federal bailouts ensured there would be "no more Lehmans or WaMus"); "Bailout Recipients," ProPublica (Feb. 16, 2021) (listing the banks, securities broker-dealers, insurance companies, and other firms that received capital assistance from the federal government during the GFC), https://projects.propublica.org/bailout/list.

${ }^{66}$ Wilmarth, Taming the Megabanks, supra note 1, at 295-98; Guillaume Adamczyk \& Bernhard Windisch, State Aid to European Banks: returning to viability (European Commission Competition State Aid Brief, Issue 2015-01, Feb. 2015), https://ec.europa.eu/competition/publications/csb/csb2015 001_en.pdf; Antonio Millaruelo and Ana del Río, "The cost of interventions since in the financial sector since 2008 in the EU countries" (Banca de Espana Analytical Article, April 6, 2017), available at http://ssrn.com/abstract=3048261; Sebastian Schich, "Insurance Companies and the Financial Crisis," 2009:2 Financial Market Trends (OECD, Oct. 2009) (describing government assistance provided to large U.S. and European insurance companies during the GFC), https://www.oecd.org/pensions/insurance/44260382.pdf.
} 
that their countries would "take decisive steps and use all available tools to support systemically important financial institutions and prevent their failure.” On February 23, 2009, U.S. bank regulators reiterated that pledge by declaring that the federal government would "preserve the viability of systemically important financial institutions." ${ }^{\prime 67}$ The bailouts that occurred on both sides of the Atlantic during the GFC established beyond any doubt that big universal banks and systemically important shadow banks were TBTF.

The pandemic crisis has not yet forced the U.S., U.K., and EU to recapitalize large financial institutions. U.S. and international bank regulators have said that the lack of failures among global systemically important banks (G-SIBs) shows that big banks are "more resilient" by virtue of the stronger capital and liquidity requirements established by G20 nations after 2009. However, regulators have also acknowledged that megabanks "benefited from the extraordinary policy measures and other supervisory and regulatory relief" that government authorities provided. ${ }^{68}$ Governments on both sides of the Atlantic provided crucial support to large banks during 2020 when they rescued short-term wholesale credit markets, gave huge amounts of financial assistance to households and business firms, and backstopped the corporate and municipal bond markets. ${ }^{69}$

The G20's post-crisis reforms required G-SIBs to maintain substantially higher levels of capital and liquidity reserves, compared with the woefully inadequate amounts they held when the GFC began in 2007. Average capital and liquidity levels for G-SIBs increased steadily

\footnotetext{
${ }^{67}$ Wilmarth, Taming the Megabanks, supra note 1, at 287, 290 (quoting pledges by the G7 finance ministers and U.S. bank regulators).

${ }^{68} 2020$ FSOC Annual Report, supra note 18, at 6, 174 (quotes); see also Basel Committee on Bank Supervision, Early lessons from the Covid-19 pandemic on the Basel reforms 13-15 (July 2021) (stating that "the lack of failure of any internationally-active bank during the pandemic demonstrates the resilience of the global banking system," but noting that "governments and central banks have provided exceptional support to the economy, indirectly supporting banks," id. at 13) [hereinafter Basel Covid-19 Report], https://www.bis.org/bcbs/publ/d521.pdf. ${ }^{69} 2020$ FSOC Annual Report, supra note 18, at 15-45, 99-103, 128-35; see also supra notes 19-30, infra notes 7375 and accompanying text.
} 
between 2012 and 2017. However, capital and liquidity levels stopped rising in 2017 and remained about the same through 2019. At the end of 2019, the Basel III supplemental leverage capital ratio for the largest global banks - widely viewed as the most binding capital standard averaged 6.4\% for U.S. G-SIBs, $4.9 \%$ for European and Canadian G-SIBs, and $6.9 \%$ for Asian G-SIBs. $^{70}$ Those ratios were far below the $15 \%$ leverage capital ratio that officials at the Federal Reserve Bank of Minneapolis and other experts have advocated as the minimum level needed to establish a truly resilient banking system that does not require frequent government bailouts. ${ }^{71}$

The pandemic crisis posed very severe challenges to the survival of universal banks and shadow banks until governments and central banks intervened. On March 16, 2020, the U.S. stock market's main indexes fell by $12 \%$ or more in the market's worst performance since the stock market crash on October 19, 1987. Bank stocks were "among the hardest hit," and the stock prices of the three largest U.S. banks dropped by $15 \%$ or more. Short-term wholesale credit markets froze, and investor runs began against money market funds. The pandemic crisis "brought the financial crisis to the brink," and "the stresses to the financial system [on March 16] were broader than many had seen," even during the GFC. ${ }^{72}$

The federal government "unleashed a barrage of government programs [to pull] the system back from collapse." The Fed provided over $\$ 50$ billion of discount window loans to

\footnotetext{
${ }^{70}$ Basel Covid-19 Report, supra note 68, at 13-15; 2020 FSOC Annual Report, supra note 18, at 6, 78-85, 174; Federal Reserve Bank of Kansas City, "Bank Capital Analysis” as of Dec. 31, 2019, https://www.kansascityfed.org/documents/6704/BankCapitalAnalysisTable_Dec312019.pdf.; see also Wilmarth, Taming the Megabanks, supra note 1, at 216-20, 303-07.

${ }^{71}$ Federal Reserve Bank of Minneapolis, The Minneapolis Plan to End Too Big to Fail 39-42, 63-65, 72-73, 88-99 (Dec. 2017), available at https://www.minneapolisfed.org/policy/endingtbtf/final-proposal; see also Wilmarth, Taming the Megabanks, supra note 1, at 304, 462 (notes 31 \& 32) (citing views of additional experts).

72 Baer, supra note 18 (second and third quotes); Caitlin McCabe, "Dow Plummets Nearly 3,000 Points as Virus Fears Spread," Wall Street Journal (Mar. 16, 2020); (first quote), https://www.wsj.com/articles/stocks-dow-slideafter-fed-slashes-rates-11584310328; see also Leonard, supra note 26 ("The crisis has strained worldwide financial markets and corporations that were already saddled with record levels of debt. It caused a financial panic in March that wasn't fully appreciated at the time.").
} 
banks, and it quickly reactivated almost all of the emergency lending facilities it used during the GFC to support large financial institutions and short-term wholesale financial markets. The Fed used its restored facilities to provide $\$ 35$ billion of loans to securities broker-dealers (many of which were affiliates of universal banks), $\$ 440$ billion of repo loans, $\$ 66$ billion of assistance to money market funds and the commercial paper market, and over $\$ 460$ billion of swap loans to foreign central banks (thereby indirectly providing dollar funding needed by foreign banks). ${ }^{73}$

The Fed also conducted "a torrent of bond buying programs to stabilize markets." The Fed purchased huge volumes of Treasury bonds and federal agency securities and added $\$ 2.85$ trillion to its balance sheet between March 11 and June 10, 2020. Congress, the Treasury and the Fed created new lending and bond-buying programs that provided large-scale financial assistance to households, small businesses, and large corporations. ${ }^{74}$ Thus, large banks "escaped bailouts [during the pandemic] primarily because their customers were bailed out instead."75

Universal banks and shadow banks would have suffered very large losses if federal agencies had not intervened. On March 15, 2020 - the day before the stock market crashed - all eight U.S. G-SIBs issued a joint press release announcing that they were facing an "unprecedented challenge" from the pandemic and were therefore suspending further stock buybacks. ${ }^{76}$ Universal banks and shadow banks benefited greatly from the Fed's quick actions to

\footnotetext{
${ }^{73}$ Baer, supra note 18 (quote); Menand, supra note 23, at 109-20, 129 (Figure 8); see also supra note 23 and accompanying text.

${ }^{74}$ Leonard, supra note 26; Menand, supra note 23, at 121-30; Nick Timiraos \& Jon Hilsenrath, "The Federal Reserve Is Changing What It Means to Be a Central Bank,” Wall Street Journal (April 27, 2020) (quote), https://www.wsj.com/articles/fate-and-history-the-fed-tosses-the-rules-to-fight-coronavirus-downturn-11587999986; FRED Fed Balance Sheet Data, supra note 8 (showing changes in the Fed's balance sheet); see also 2020 FSOC Annual Report, supra note 18, at 15-29, 33-37, 43-45, 106, 141-43; supra notes 24-27 and accompanying text.

${ }^{75}$ Rochelle Toplensky, “The Covid-19 Pandemic Hasn’t Truly Tested Banks,” Wall Street Journal (July 13, 2021), https://www.wsj.com/articles/the-covid-19-pandemic-hasnt-truly-tested-banks-11626170102.

${ }^{76}$ Laura Noonan \& Robert Armstrong, "Coronavirus forces eight big US banks to suspend share buybacks," Financial Times (Mar. 15, 2020), https://www.ft.com/content/a4660928-670c-11ea-800d-da70cff6e4d3.
} 
rescue money market funds, repos, and the commercial paper market because they relied significantly on funding from all three sources. ${ }^{77}$

Even with the federal government's massive support, stock prices for U.S. G-SIBs performed "notably worse than the S\&P 500 index" between March and June 2020. A widelyused stock price index for 24 large U.S. banks (including six of the eight U.S. G-SIBs) dropped by $40 \%$ between January and May 2020, compared to a $13 \%$ decline for the broad Russell 3000 index. Risk spreads for credit default swaps issued by the six largest U.S. G-SIBs rose significantly during the spring of 2020, although they did not reach the levels recorded in $2008 .^{78}$ In June 2020, the Fed conducted a stress test of the 34 largest domestic and foreign banks operating in the U.S. The Fed estimated - based on alternative scenarios reflecting differing degrees of severity for the pandemic's impact - that the stress-tested banks could suffer total losses of $\$ 560$ billion to $\$ 700$ billion over the next nine calendar quarters. The Fed's stress test also determined that capital ratios for "several" banks would fall close to their "minimum capital requirements."79 A contemporaneous stress test performed by four Harvard economists (including former Fed Governor Jeremy Stein) estimated that the 21 largest U.S. banks could suffer losses of $\$ 390$ billion to $\$ 550$ billion during the same period, and four or five U.S. G-SIBs might fall below their minimum capital requirements. ${ }^{80}$ Thus, both stress tests indicated that

\footnotetext{
772020 FSOC Annual Report, supra note 18, at 81 (Chart 3.5.1.9) (showing that U.S. G-SIBs relied on short-term funding for $25 \%$ of their total liabilities); Kaiser-Schatzlein, supra note 34 (stating that the Fed "bailed out huge asset managers and other shadow banks by backstopping money market funds, repurchase agreements, and other corporate financing tools," which served as their "main financing avenues").

782020 FSOC Annual Report, supra note 18, at 86-87 (quote); Michael Blank, Samuel G. Hanson, Jeremy Stein \& Adi Sunderam, "How Should U.S. Bank Regulators Respond to the COVID-19 Crisis?" (Hutchins Center Working Paper \#63, June 2020) at 5, 24 (Table 2) (showing the performance of the 24-bank stock index), available at https://scholar.harvard.edu/files/stein/files/wp63 blank-et-al_final.pdf; Gordon Scott, "KBW Bank Index," Investopedia (May 21, 2021) (describing the KBW Bank Index, listed as "BKX” on Nasdaq), https://www.investopedia.com/terms/k/kbw-bank-index.asp.

792020 FSOC Annual Report, supra note 18, at 87-89.

${ }^{80}$ Blank, Hanson \& Stein \& Sunderam, supra note 78, at 6-9 \& 25-26 (Tables 3 \& 4).
} 
major U.S. banks faced very serious potential threats in mid-2020, even with the extensive help they received from the federal government.

Large banks in other advanced economies also experienced severe financial stress during 2020, as indicated by widespread downgrades in their credit ratings and significantly higher risk spreads for their bonds. In October 2020, the International Monetary Fund (IMF) performed a "global stress test" of 350 large banks in 29 countries with advanced banking systems. The IMF estimated - based on alternative scenarios for the pandemic's potential impact - that total capital levels for the stress-tested banks would fall \$110 billion to $\$ 220$ billion below their combined minimum capital requirements, even after accounting for the vast support they received from governments and central banks. ${ }^{81}$ All three of the foregoing stress tests assumed that current Basel III capital standards are sufficient to assure the resilience of large banks - an assumption that many experts have challenged, as indicated above.

Minneapolis Fed President Neel Kashkari recently stated that "[f]iscal authorities were right to be so forceful and proactive in supporting the economy during the Covid downturn." He emphasized that "this was also a banking bailout. Absent these fiscal interventions, losses in the banking sector would have been much larger." 82 A recent New York Fed staff study concluded that implicit government subsidies for systemically important banks around the world became significantly larger during the pandemic crisis as a result of "unprecedented government support." 83 Thus, the enormous rescue programs established by governments and central banks during the pandemic entrenched the TBTF status of large universal banks.

\footnotetext{
812021 BIS-AEO, supra note 17, at 4-6 \& Graph I.4; 2020 BIS-AEO, supra note 16, at 17-18, 20; Int'1 Monetary Fund, Global Financial Stability Report, at 15-16 \& Chapter 4 (October 2020), https://www.imf.org/en/Publications/GFSR/Issues/2020/10/13/global-financial-stability-report-october-2020.

${ }^{82}$ Neel Kashkari, "Banks cannot expect governments to bail them out of every crisis," Financial Times (June 28, 2021), https://www.ft.com/content/760f8a05-d5be-4066-8f3d-802d78c33bce.

83 Asani Sarkar, "Did Subsidies to Too-Big-to-Fail Banks Increase during the COVID-19 Pandemic?", Liberty Street Economics (Fed. Res. Bank of NY, Feb. 11, 2021) (blog post),
} 
Private equity firms also benefited greatly from those rescue programs. Private equity

firms are among the most significant shadow banks, and they managed $\$ 4$ trillion of assets at the beginning of 2020. Several of the largest private equity firms became financial conglomerates after the GFC by establishing broker-dealer subsidiaries and by acquiring insurance companies. Private equity firms have used their broader resources to finance corporate buyouts by underwriting syndicated leveraged loans and high-yield bonds. Today's leading private equity firms compete directly with universal banks, and they strongly resemble the "Big Five" securities broker-dealers that were major players on Wall Street when the GFC began in 2007. The largest private equity firms essentially replaced the "Big Five" broker-dealers after those institutions either failed, were acquired by universal banks, or became universal banks themselves during $2008 .^{84}$

Private equity firms arranged corporate buyouts valued at more than $\$ 3$ trillion worldwide between 2010 and 2019. Most of those buyouts were highly leveraged transactions that left acquired firms with heavy debt burdens. Consequently, many of the 35,000 U.S.

https://libertystreeteconomics.newyorkfed.org/2021/02/did-subsidies-to-too-big-to-fail-banks-increase-during-thecovid-19-pandemicl.

${ }^{84}$ Andrew F. Tuch, "The Remaking of Wall Street," 7 Harvard Business Law Review 315 (2017); see also Joe Rennison, Eric Platt \& Sujeet Indap, "Private credit joins private equity to freeze out banks," Financial Times (July 15, 2021), https://www.ft.com/content/0a67e36e-b42f-42e1-8c17-042108fb014e; Mark Vandevelde, "KKR to buy life insurer Global Atlantic for \$4.4bn," Financial Times (July 8, 2020), https://www.ft.com/content/287774db-f2724e36-b0f4-8fadcbf2033b; Mark Vandevelde \& Sujeet Indap, "Apollo: how a private equity giant is navigating the crisis," Financial Times (April 29, 2020), https://www.ft.com/content/6fce9808-84ab-11ea-b555-37a289098206; Kaye Wiggins, Mark Vandevelde \& Robin Wigglesworth, "Coronavirus: private equity's bailout moment," Financial Times (April 26, 2020), https://www.ft.com/content/f7cc82d7-70b9-40c3-b4a0-815ebc5d99d5; Kaye Wiggins, “Ares raises $€ 11$ bn private debt fund amid alternative lending rush," Financial Times (April 29, 2021), https://www.ft.com/content/a949bcbf-0081-405d-ad8e-4d438f2f9e88; see also Wilmarth, Taming the Megabanks, supra note 1, at 266-69, 276-87 (discussing the failure of Lehman Brothers, the emergency acquisitions of Bear Stearns by JPMorgan Chase and of Merrill Lynch by Bank of America, and the emergency conversions of Goldman Sachs and Morgan Stanley into universal banks). 
companies controlled by private equity firms in early 2020 faced a high risk of failure after the pandemic crisis began. ${ }^{85}$

The four largest private equity firms - Apollo, Blackstone, Carlyle, and KKR - reported large losses during March and April 2020, and their market values plummeted. ${ }^{86}$ Credit ratings agencies downgraded almost $\$ 1$ trillion of U.S. corporate debts during that period. Even after the Fed's early interventions in March, markets for leveraged loans and noninvestment-grade (junk) bonds remained virtually frozen. Many heavily indebted companies could not pay or refinance their debts. Private equity firms appeared to be "facing a year of reckoning," as their "often highly-leveraged portfolio companies confronted the worst economic outlook since the Great Depression." 87

\footnotetext{
852020 FSOC Annual Report, supra note 18, at 111-12; Eisinger, supra note 34; Bethany McLean, "Too Big to Fail, COVID-19 Edition: How Private Equity Is Winning the Coronavirus Crisis," Vanity Fair (April 9, 2020), https://www.vanityfair.com/news/2020/04/how-private-equity-is-winnint-the-cornoavirus-crisis; Wiggins, Vandevelde \& Wigglesworth, supra note 84 (including "Private equity-backed buyout volumes" graph); see also Javier Espinosa \& Eric Platt, "Private equity races to spend \$2.5 trillion cash pile," Financial Times (June 27, 2019), https://www.ft.com/content/2f777656-9854-11e9-9573-ee5cbb98ed36; Mark Vandevelde, "The leveraging of America: how companies became addicted to debt," Financial Times (July 10, 2020), https://www.ft.com/content/c732fded-5252-4333-a3f8-80b767508bbc.

${ }^{86}$ Miriam Gottfried, “Apollo Is Latest Private-Equity Firm Hammered by Coronavirus Rout," Wall Street Journal (May 1, 2020) (reporting a \$1 billion net loss), https://www.wsj.com/articles/apollo-is-latest-private-equity-firmhammered-by-coronavirus-rout-11588330800; Miriam Gottfried, "Blackstone Battered by Selloff," Wall Street Journal (April 23, 2020) (reporting a \$1.1 billion net loss); Miriam Gottfried, "Carlyle Reports First-Quarter Loss," Wall Street Journal (April 30, 2020) (reporting a net loss of over $\$ 600$ million), https://www.wsj.com/articles/carlyle-posts-first-quarter-loss-11588242603?st=0ok95m4m06lkc0v; Miriam Gottfried \& Allison Prang, "KKR Posts Loss, but Outpaces Market,” Wall Street Journal (April 30, 2020), B10 (reporting a $\$ 1.3$ billion net loss); Vandevelde \& Indap, supra note 84 (reporting that Apollo's stock price dropped by 50\% during March 2020); William Louch, "Rout Hurts Lenders to Small Businesses," Wall Street Journal (Mar. 23, 2020) (reporting that market values for business development lenders owned by Carlyle and KKR fell by more than 50\% during March 2020).

${ }^{87} 2020$ FSOC Annual Report, supra note 18, at 17-20; McLean, supra note 85; Joe Rennison, "Downgrades flood junk bond market with 'fallen angels'," Financial Times (April 6, 2020), https://www.ft.com/content/72641a3f5c11-40b1-923a-7aeefbb89d7f; Kaye Wiggins, "Private equity dealmaking defies pandemic to hit post-crisis high," Financial Times (Dec. 23, 2020) (quote), https://www.ft.com/content/3091dd08-0301-424e-a049-7227a4883ef2; Wiggins, Vandevelde \& Wigglesworth, supra note 84; see also Shubham Saharan, "Credit rating upgrades hit record pace as US economy rebounds," Financial Times (July 15, 2021) (reporting that nearly \$1 trillion of U.S. corporate debts were downgraded during March and April 2020), https://www.ft.com/content/76893129-5e6e-435caa47-c22e174ec195.
} 
Private equity firms and their allies aggressively lobbied the federal government to help their endangered portfolio companies. On April 9, 2020, the Fed agreed to expand its programs for buying corporate bonds and bond ETFs to include bonds and leveraged loans issued by companies whose credit ratings had been downgraded to noninvestment grade (junk) since the pandemic's outbreak. The Fed's expansion of its corporate bond programs “provided a lifeline to corporate debt rated below investment grade" and ensured that private equity firms would have "continued access to cheap credit for new deals." Many observers viewed the Fed's action as "an indirect bailout of the private equity industry." 88

In addition, policymakers on both sides of the Atlantic allowed companies controlled by private equity firms to receive government-guaranteed pandemic loans. Generous support from governments and central banks enabled the private equity industry to recover rapidly during the second half of 2020. Private equity firms arranged worldwide buyouts valued at $\$ 560$ billion in 2020 - the highest level since 2007 - and they arranged another $\$ 500$ billion of such deals during the first half of 2021. ${ }^{89}$ Rescue programs during the pandemic crisis thus affirmed the TBTF status of large shadow banks as well as universal banks. ${ }^{90}$

\footnotetext{
${ }^{88}$ Joe Rennison, Robert Wigglesworth \& Colby Smith, "Federal Reserve enters new territory with support for risky debt," Financial Times (April 9, 2020) (first and third quotes), https://www.ft.com/content/c0b78bc9-0ea8-461ca5a2-89067ca94ea4; Wiggins, supra note 87 (second quote); see also Kate Duguid \& Megan Davies, "Junk bonds rally after Fed provides lifeline to riskier credits," Reuters (April 9, 2021), https://www.reuters.com/article/us-usajunkbonds/junk-bond-prices-rally-after-fed-offers-lifeline-to-riskier-credits-idUSKCN21R2HC; Eisinger, supra note 34; Timiraos \& Hilsenrath, supra note 74.

${ }^{89}$ Ortenca Allaj \& Kaye Wiggins, "Private equity breaks 40-year deal with $\$ 500 \mathrm{bn}$ of deals," Financial Times (July 1, 2021), https://www.ft.com/content/cd9571a3-726c-4995-9954-23a8dcf12b19; Daniel Thomas \& Kaye Wiggins, "Private equity-owned companies win access to UK emergency funds," Financial Times (Sept. 25, 2020), https://www.ft.com/content/91057524-d8c3-4912-b5df-572f46d7f050; Wiggins, supra note 85; see also Nick Schwellenbach \& David Szakonyi, "Inside the Pandemic Cash Bonanza for Private Equity-Backed Firms," Daily Beast (July 15, 2020), https://www.thedailybeast.com/private-equity-backed-firms-got-ppp-funds-for-businesses-hitby-coronavirus.

${ }^{90}$ Eisinger, supra note 34; Megan Tobias Neely \& Donna Carmichael, "Profiting on Crisis: How Predatory Investors Have Worsened Inequality in the Coronavirus Crisis," American Behavioral Scientist (2021) (forthcoming), https://journals.sagepub.com/doi/pdf/10.1177/00027642211003162; Timiraos \& Hilsenrath, supra note 74 .
} 


\section{Bailouts during the pandemic crisis perpetuate the global doom loop, which creates great dangers for the financial system, general economy, and society.}

The pandemic crisis confirms that governments, central banks, universal banks, shadow banks, and wealthy investors remain trapped in a global doom loop of toxic mutual dependence. Whenever a serious economic or financial disruption occurs, governments and central banks arrange huge bailouts to prevent disorderly failures of universal banks and systemically important shadow banks. Central banks maintain unconventional monetary policies that keep interest rates low, boost asset prices, and facilitate the continued growth of public and private debts. Universal banks and shadow banks eagerly underwrite higher levels of private and public debts, given the lucrative fees they earn from such transactions. Wealthy investors buy higherrisk financial assets in a "search for yield," based on their expectation that governments and central banks will take all necessary steps to preserve economic and financial stability. ${ }^{91}$

As shown above, the global doom loop has produced an infernal cycle of ever-increasing public and private debts and ever-larger bailouts. From December 2007 through March 2021 -a period that included immense government rescue programs during the GFC and the pandemic crisis - total U.S. public and private debts increased from $\$ 53.8$ trillion to $\$ 83.9$ trillion. The federal government's rapidly growing debt burden accounted for over $60 \%$ of that increase, rising from $\$ 9.2$ trillion (63\% of U.S. GDP) in December 2007 to $\$ 28.1$ trillion (127\% of U.S. GDP) in March 2021. ${ }^{92}$ Similarly, global public and private debts expanded from $\$ 167$ trillion in December 2007 to $\$ 289$ trillion in March 2021. Rising worldwide government debts accounted

\footnotetext{
${ }^{91}$ Arthur E. Wilmarth, Jr., "To restore financial stability, bring back Glass-Steagall,” The Hill (Sept. 30, 2020), https://thehill.com/opinion/finance/518803-to-restore-financial-stability-bring-back-glass-steagall; see also Wilmarth, Taming the Megabanks, supra note 1, at 12-13, 325-27, 353-56 (discussing the global doom loop). ${ }^{92}$ Fed Flow of Funds Data, supra note 10, at 7, 9 (Tables D.3 \& F.2); FRED Federal Debt Data, supra note 25; FRED GDP Data, supra note 28.
} 
for $40 \%$ of that increase, growing from $\$ 34.8$ trillion (60\% of global GDP) in 2007 to $\$ 83.4$ trillion (106.5\% of global GDP) in $2021 .^{93}$

The global doom loop creates unsustainable risks and burdens for the financial system, the broader economy, and society. In July 2021, a U.K. House of Lords committee issued a report criticizing the quantitative easing (QE) policy of the Bank of England (BoE). ${ }^{94} \mathrm{QE}$ policies are a central component of the global doom loop, as they enable central banks to buy huge volumes of government debt securities and other financial assets, thereby supporting the growth and reducing the debt service costs of public and private borrowings. The House of Lords committee identified five very troubling features of QE policies.

First, the committee pointed out that "[n]o central bank has managed successfully to reverse quantitative easing over the medium to long term." The Bank of Japan (BoJ) was the first central bank to adopt a QE policy in 2001, and the BoJ has never exited that policy after buying almost $\$ 7$ trillion of government bonds and other financial assets. The Fed tried to unwind its QE policy in 2013 and again in 2017-18, but the Fed abandoned both attempts after they triggered disruptive selloffs by frightened investors in global financial markets. The House of Lords committee warned that "central banks are facing a 'no-exit paradigm' from quantitative easing. ... [T]he scale of quantitative easing has been increased repeatedly. ... This has only served to exacerbate the challenges involved in unwinding the policy."95

\footnotetext{
${ }^{93} 2021$ IIF Global Debt Monitor, supra note 29; Wadhwa, supra note 27; Wilmarth, Taming the Megabanks, supra note 1, at 321-22 \& Figure 12.1.

${ }^{94}$ Quantitative easing; a dangerous addiction? (U.K. House of Lords Economic Affairs Committee, July 16, 2021) (1 Report of Session 2019-21, HL Paper 42) [hereinafter 2021 House of Lords QE Report], https://publications.parliament.uk/pa/ld5802/ldselect/ldeconaf/42/4202.htm.

${ }^{95}$ Id., Summary (first quote), Chapter 1 (IIII 8-10 \& Figure 2), Chapter 4 (IIIT 160, 164-65 \& 177 (first part of second quote) (emphasis in original)) \& Chapter 5 (II 180) (remainder of second quote) (emphasis in original)); see also Wilmarth, Taming the Megabanks, supra note 1, at 321-27 (discussing the inability of central banks to exit their QE policies); Leonard, supra note 26 (same).
} 
Michael Forsyth, the committee's chair, expressed his concern that "[t]he Bank of England has become addicted to quantitative easing." 96

Second, the committee stated that the BoE's QE program may have violated the BoE's mandate by "effectively monetizing the government deficit." ${ }^{97}$ During the pandemic crisis, the BoE doubled the size of its balance sheet by authorizing the purchases of $£ 450$ billion of U.K. government bonds. The BoE's purchases of government bonds "aligned closely" with the volume and timing of government bond issues made by the U.K. Treasury during the crisis. Most of the 18 largest investors in U.K. government bonds and several analysts concluded that "the Bank of England had bought gilts to keep the Government's borrowing costs down." The House of Lords committee determined that there was a "widespread perception ... that

\section{financing the Government's deficit spending was a significant reason for quantitative} easing during the COVID-19 pandemic." 98

Third, the committee was alarmed by QE's potential to undermine the BoE's political independence as well as the credibility of the BoE's mandate to control inflation and maintain stable prices. The committee stated that QE has “made Bank of England and HM Treasury policymaking more interdependent, blurring monetary and fiscal policy, and this has started to erode the perception that the Bank has acted wholly independently of political considerations." Some experts stated that the BoE faced strong political pressure to keep

\footnotetext{
${ }^{96}$ William Schomberg, "Bank of England addicted to bond-buying - UK lawmaker panel chair," Reuters (July 15, 2021) (quoting Lord Forsyth), https://www.reuters.com/world/uk/bank-england-addicted-bond-buying-uklawmaker-panel-chair-2021-07-15/.

${ }_{97} 2021$ House of Lords QE Report, supra note 94, Summary \& Chapter 5 (II 74) (quoting Frances Coppola).

${ }^{98}$ Id., Summary (first quote), Chapter 1 (IIII 12-18), Chapter 3 (IIII 72-78, 85, \& 88-89) (third quote) (emphasis in original), \& Chapter 4 (II 172 (second quote)); see also Tommy Stubbington \& Chris Giles, "Investors sceptical over Bank of England's QE programme," Financial Times (Jan. 4, 2021) (A survey of the 18 largest investors in UK government bonds showed that the "overwhelming majority" was "convinced the BoE bought an additional £450bn of gilts during the Covid-19 crisis in order to ease the government's huge programme of borrowing by keeping debt service costs at rock bottom"), https://www.ft.com/content/f92b6c67-15ef-460f-8655-e458f2fe2487.
} 
interest rates low for an extended period to suppress government borrowing costs, thereby weakening the BoE's ability to respond to significant increases in inflation. The committee warned that "if inflation rises, the Bank may come under political pressure to not raise interest rates to control inflation because the risk to the public finances and debt sustainability would have increased significantly."${ }^{.99}$

Fourth, the committee found that "quantitative easing has distributional outcomes that exacerbate wealth inequalities" because the BoE's ultra-low interest rates and large infusions of liquidity boosted market prices for housing and higher-risk financial investments, which are primarily owned by the richest households. In the committee's view, QE "benefited wealthy asset holders disproportionately by artificially inflating asset prices. On balance, we conclude that the evidence shows that quantitative easing has exacerbated wealth inequalities." 100

Finally, the House of Lords committee expressed its concern that QE could "compromise financial stability" by encouraging "excessive and potentially destabilising risk-taking in markets." Mohamed El-Erian told the committee that "consistent central bank intervention through quantitative easing" encouraged market participants to "take excessive risks in the knowledge that central banks will provide support if financial stability is threatened." Lee Bucheit stated that "the normal risk aversion of private sector lenders has been anaesthetised by the fact that they are stuffed [by central banks] with liquidity that they must re-deploy." 101 The

\footnotetext{
${ }^{99}$ Id., Chapter 4 (IIII 115, 138, 151 (second quote) (emphasis in original) \& 168-69)) \& Chapter 5 (II 182-83) (first quote) (emphasis in original)).

${ }^{100}$ Id., Chapter 2 (III 57, 61-64, 68 (second quote) \& 70 (first quote) (emphasis in original).

1012021 House of Lords QE Report, supra note 94, Chapter 2 (III 65-66) (summarizing and quoting statements by Messrs. El-Erian and Bucheit).
} 
committee's chair, Lord Forsyth, concluded that QE presents "a serious danger to the long-term

health of the public finances."102

The disturbing problems identified by the House of Lords committee with regard to the BoE's QE policy apply equally to the unconventional monetary policies of the Fed and other leading central banks. As the committee pointed out, no major central bank has successfully exited from QE. Due to the close coordination between government deficit spending on stimulus programs and central bank purchases of government bonds, some analysts believe that QE policies have effectively monetized the growth of government debt. ${ }^{103}$ The BoE's purchases of $£ 450$ billion of U.K. government bonds since March 2020 have nearly matched the $£ 486$ billion of bonds issued by the U.K. government to finance its response to the pandemic. ${ }^{104}$

The Fed bought $\$ 2.44$ trillion of U.S. Treasury securities between March 2020 and March 2021, equal to half of the $\$ 4.91$ increase in federal debt during that period. The Fed's purchases nearly doubled its percentage ownership of outstanding federal debt from $9.3 \%$ to $17.6 \%$, making it "the biggest player in the US bond market." 105 Some observers have concluded that

102 Schomberg, supra note 96 (quoting Lord Forsyth).

${ }^{103}$ Darrell Delamaide, "Central Bank Watch: Concern Growing About Central Banks Monetizing Government Debt," Investing.com (June 14, 2021), https://www.investing.com/analysis/fed-watch-concern-growing-aboutcentral-banks-monetizing-government-debt-200585888; James A Dorn, "Fiscal Dominance and Fed Complacency" (April 8, 2021), https://www.cato.org/blog/fiscal-dominance-fed-complacency; Paul Wallace, "Has the Bank of England Gone Too Far?”, Prospect Magazine (April 22, 2020), https://www.prospectmagazine.co.uk/economicsand-finance/andrew-bailey-governor-bank-of-england-interest-rate-coronavirus-covid-19; see also Timiraos \& Hilsenrath, supra note 74 ("[W]ith large-scale purchases of U.S. Treasury securities, the Fed is stretching the boundaries for what a central bank will do to finance soaring federal debt .... The Fed's actions represent a level of cooperation with Congress and the Treasury not seen since World War II.").

104 Andy Bruce, "UK gilt issuance to be second-highest on record at almost 250 billion pounds: Reuters poll," Reuters (Mar. 2, 2021) (reporting that the U.K. Treasury issued $£ 485.5$ billion of bonds in $2020-21$ "to finance the economic response to the COVID-19 pandemic"), https://www.reuters.com/article/us-britain-budget-bonds/uk-giltissuance-to-be-second-highest-on-record-at-almost-250-billion-pounds-reuters-poll-idUSKBN2AU16D; supra note 98 and accompanying text (discussing the BoE’s decisions to buy $£ 450$ billion of government bonds since the pandemic's outbreak).

${ }^{105}$ Federal Reserve Bank of St. Louis, FRED Economic Data: “[Federal Reserve] Assets: [U.S. Treasury] Securities Held Outright” (July 21, 2021), https://fred.stlouisfed.org/series/TREAST; FRED Fed Balance Sheet Data, supra note 8; see also Peter Schiff, "The Fed Monetized More than Half the Massive Federal Pandemic Debt" (May 26, 2021) (quote), https://schiffgold.com/key-gold-news/the-fed-monetized-more-than-half-the-massive-federalpandemic-debt/. 
QE programs are a form of "financial repression," which is designed to suppress interest rates on government bonds and thereby reduce government borrowing and debt service costs. ${ }^{106}$

Considerable evidence also supports the House of Lords committee's view that unconventional monetary policies since 2008 have increased wealth inequality and encouraged excessive risk-taking by financial institutions and investors. The ultra-low interest rate policies and $\mathrm{QE}$ programs of central banks have (i) greatly reduced the returns to ordinary savers from bank deposits and other low-risk investments, (ii) encouraged investors to buy higher-risk, higher-yielding investments, and (iii) increased the market values of housing and other higherrisk assets, resulting in disproportionate wealth gains for the richest households, which own the largest share of those assets. Government rescues of financial institutions, financial markets, and wealthy investors during the GFC and the pandemic have further increased the incentives and payoffs for high-risk, high-reward investment strategies. Statistical indicators of wealth inequality have risen substantially since 2008 and accelerated during the pandemic. ${ }^{107}$

\footnotetext{
${ }^{106}$ Robert Armstrong, "Real rates as tools of repression," Financial Times (July 29, 2021) (quoting Jim Reid and Thomas Mayer), https://www.ft.com/content/dc112004-ce99-4959-9988-1b0d7c12d318. A 2015 study by Carmen Reinhart and Belen Sbrancia determined that the U.S., U.K., and other advanced countries used policies of "financial repression" to reduce the costs of servicing and repaying their World War II debts between 1945 and 1980. In addition, Reinhart and Sbrancia noted that the extraordinary purchases of government bonds by central banks during and after the GFC "call[ed] into question what the information content of [government] bond prices are relatively to their underlying risk profile. This decoupling between interest rates and risk is a common feature of financially repressed systems." Carmen M. Reinhart \& M. Belen Sbrancia, "The Liquidation of Government Debt," (IMF Working Paper 15/7, Jan. 2015) (quote at 40), available at http://ssrn.com/abstract=2568600.

${ }^{107}$ Leonard, supra note 26 (stating that ultra-low interest rates and QE policies have encouraged a "search for yield" among investors, providing a "classic recipe for creating asset bubbles"); Joe Rennison, "How the Fed's fine intentions feed US wealth inequality," Financial Times (July 26, 2021) ("Wealth inequality in the US has reached a record level since the outbreak of the pandemic, and the Federal Reserve is partially responsible ... [because] its stimulus has also fired up the price of assets held by the wealthy"), https://www.ft.com/content/57730688-aa494549-a127-4b2d625260a4; Valentina Romei \& Chris Giles, "Pandemic fuels broadest global house price boom in two decades," Financial Times (Aug. 1, 2021) ("House prices are booming in almost every major economy" due to “"[e]xtremely accommodating financial conditions' with record-low interest rates," which support "[m]ortgage growth [for] people with strong financial positions") (quoting Claudio Borio), https://www.ft.com/content/491a245d-4af7-4cad-b860-6ba51b86b45f; Ruchil Sharma, "The billionaire boom: how the super-rich soaked up Covid cash," Financial Times (May 14, 2021) (“As the virus spread, central banks injected $\$ 9$ tn into economies worldwide, aiming to keep the world economy afloat. Much of that stimulus has gone into financial markets, and from there into the net worth of the ultra-rich. The total wealth of billionaires worldwide rose by $\$ 5$ tn to $\$ 13$ tn in 12 months, the most dramatic surge ever registered on the annual billionaire list compiled by
} 
In addition to helping wealthy investors, central banks "pick[ed] winners and losers" among private-sector companies when they selected the recipients of their corporate bondbuying and corporate lending programs during 2020. Both forms of favoritism could turn public opinion against central banks. The Occupy Wall Street and Tea Party movements reflected a widely-shared view that the Fed bailed out Wall Street banks and influential investors during the GFC. The rise of a similar popular consensus that the Fed rescued powerful financial institutions, big corporations, and wealthy investors during the pandemic could further erode public support for the Fed. ${ }^{108}$

An additional threat to the political independence of central banks arises out of the close coordination between central bank bond-buying programs and government fiscal stimulus efforts during the pandemic. The Fed, the BoE, and the ECB have maintained ultra-low interest rates and QE policies and have expressed their willingness to allow inflation rates to exceed $2 \%$ for extended periods of time. ${ }^{109}$ The heads of Belgium's and Germany's central banks recently

Forbes magazine."), https://www.ft.com/content/747a76dd-f018-4d0d-a9f3-4069bf2f5a93; Wilmarth, Taming the Megabanks, supra note 1, at 293-95, 324-25 (reviewing evidence that QE policies increased wealth inequality between 2008 and 2019); Yardeni \& Quintana, supra note 22, at 3 (Figure 6) (showing a relatively high level of consistency during 2009-21 between growth in the balance sheets of the Fed, BoJ, and ECB and increases in the S\&P 500 index); see also Emmanuel Saez \& Gabriel Zucman, "The Rise in Income and Wealth Inequality in America," 34(4) Journal of Economic Perspectives 3, 8-12 (2020) (finding that the share of U.S. household wealth held by the richest 10\% of "tax units" (individuals or households) rose from 68\% to 78\% between 1989 and 2018, while the share held by the richest $1 \%$ grew from $28 \%$ to $38 \%$; substantial portions of both increases occurred between 2008 and 2018, see id. at 10 (Figure 1)).

${ }^{108}$ Eisinger, supra note 34; Kathryn Judge, "The Truth About the COVID-19 Bailouts," Fortune (April 15, 2020), https://www.forbes.com/sites/kathrynjudge/2020/04/15/the-covid-19-bailouts/?sh=487f9dbe3b77; Leonard, supra note 26 (quoting Kenneth Rogoff's warning about the growing risks of a "political backlash" because "the Fed has been picking winners and losers in debt markets, buying the debt of some cities and corporations and not others"); Peter Schiff, "Which Corporate Bonds [Has] The Fed Bought So Far?" (June 29, 2020) (contending that "the central bank is ultimately picking winners and losers" by purchasing corporate bonds of selected companies), https://schiffgold.com/key-gold-news/which-corporate-bonds-the-fed-has-bought-so-far/; Wilmarth, Taming the Megabanks, supra note 1, at 297-98 (discussing the populist backlash against bailouts during the GFC); see also Timiraos \& Hilsenrath, supra note 74 (describing the dangers that "politicians will grow accustomed to directing the [Fed] to fix problems its tools aren't designed to solve, and that public discontent about the central bank's choices will erode its authority over time").

${ }^{109}$ See, e.g., Martin Arnold, "ECB changes inflation target, leaving extra room to keep rates low," Financial Times (July 8, 2021), https://www.ft.com/content/ab3b8c36-2199-4230-b9b3-b9e12c09d44b; Chris Giles, "BoE signals 'modest tightening' of monetary policy in next 2 years," Financial Times (Aug. 5, 2021) (discussing the BoE's 
criticized the ECB for continuing to buy large amounts of EU government bonds to "cap

borrowing costs" for those governments. The Belgian central bank chief warned that the ECB

was losing its political independence as it became subject to the "fiscal dominance" of EU

governments. $^{110}$

The Fed announced in July 2021 that it would maintain near-zero interest rates and continue to buy $\$ 120$ billion of Treasury securities and federal agency mortgage-backed securities each month until the U.S. economy achieved "substantial further progress . . . toward its maximum employment and price stability goals." Fed Chair Jerome Powell stated that the Fed would consider whether to "taper" its bond purchases at future meetings, but he "offered few specifics." He also indicated that the Fed was "nowhere near considering plans to raise interest rates," and he reiterated "his longstanding view that recent surges in inflation are likely to fade over time."111 Powell's positions on monetary policy during the pandemic have been "in lockstep with the White House." It seems highly unlikely that he would be appointed or confirmed for another term as Chair in 2022 if he advocated a significant change in the Fed's "highly accommodative, dovish response to the pandemic."112

decision to maintain its short-term interest rate target at $0.1 \%$ and to continue its previously-approved QE purchases of U.K. government bonds, and reporting that the BoE expressed "no urgency . . for immediate action to raise interest rates," although the BoE stated that "some modest tightening of monetary policy is likely to be necessary" within the next two years), https://www.ft.com/content/80de9d5d-42c5-47f0-bc86-a46d05291691; James Politi \& Colby Smith, "Democrats weigh backing Jay Powell as Fed leadership choice looms," Financial Times (July 18, 2021) (stating that the Fed under Powell's leadership has adopted "a new policy framework that promises to hold off on pre-emptive rate increases and pursue full employment more fully than in the past"), https://www.ft.com/content/33ee0f1d-5606-4195-b455-cdddc97d2969.

110 "UPDATE 1-ECB buys more bonds than countries sell to cap yields," Reuters (Aug. 2, 2021) (discussing warnings by Pierre Wunsch and Jens Weidmann), https://www.reuters.com/article/ecb-qe/update-1-ecb-buys-morebonds-than-countries-sell-to-cap-yields-idUSL8N2P94I7,

${ }^{111}$ Board of Governors of the Federal Reserve System, "Press Release: Federal Reserve issues FOMC statement" (July 28, 2021) (quote), https://www.federalreserve.gov/newsevents/pressreleases/monetary20210728a.htm; Nick Timiraos, "Fed Says Economy Has Progressed Toward Goals, Tees Up Bond Taper," Wall Street Journal (July 28, 2021) (summarizing comments made by Mr. Powell), https://www.wsj.com/articles/fed-says-economy-has-madeprogress-toward-its-goals-teeing-up-bond-taper-11627495233.

${ }_{112}$ Steven T. Dennis \& Saleha Mohsin, "Biden Fed Pick Pits Powell Against Liberal Push for Regulation," Bloomberg Law (Aug. 3, 2021) (describing concerns among Republican Senators that Powell would not be willing to support an anti-inflation policy opposed by the Biden Administration, due to the expiration of Powell's term as 
As the House of Lords committee warned, the apparent erosion of political independence for central banks could severely weaken their ability to control inflation. The Fed, the BoE, and other central banks lost much of their independence and credibility during the 1960s and 1970s, when they adopted easy-money policies that supported extensive deficit spending by their governments and failed to prevent high inflation rates. ${ }^{113}$ Today there are growing concerns that (1) huge government deficits and extraordinary monetary stimulus by central banks could produce significant increases in inflation, and (2) political pressures on central banks will prevent them from responding effectively to rising inflation rates. ${ }^{114}$ The potential threat of high inflation should not be disregarded, as past inflationary episodes have frequently led to deep recessions with heavy losses for societies. Periods of high inflation and severe recessions are

Chair in 2022); Victoria Guida, “'Jay's Job to Lose': Powell's reappointment by Biden as Fed chief hangs on inflation," Politico (July 1, 2021) (stating that Powell's dovish monetary policy during the pandemic placed him "in lockstep with the White House"), https://www.politico.com/news/2021/07/01/powell-biden-fed-interest-rates497425; Politi \& Smith, supra note 109 (discussing the Fed's "highly accommodative, dovish response to the pandemic" under Powell's leadership); Nick Timiraos \& Andrew Restuccia, "Fed Chairman Powell Enjoys Support for Reappointment, but He's Not a Lock," Wall Street Journal (July 21, 2021) (reporting that some progressive Democrats supported Powell as being "uniquely suited to deliver what many Democrats want: a lower-interest-rate policy that gives priority to lower unemployment"), https://www.wsj.com/articles/fed-chair-powell-enjoys-supportfor-reappointment-but-hes-not-a-lock-11626859803.

${ }^{113}$ For discussions of the loss of credibility by the Fed, the BoE, and other central banks during the "Great Inflation" of the 1960s and 1970s, see Michael D. Bordo \& Pierre L. Siklos, "Central Bank Credibility: An Historical and Quantitative Exploration" (National Bureau of Economic Research Working Paper 20824, Jan. 2015), http://www.nber.org/papers/w28024; Allan H. Meltzer, A History of the Federal Reserve, Volume II, Chapters 4-7 (Univ. of Chicago Press, 2009).

${ }^{114}$ For discussions of the potential risks of higher inflation and the reluctance of leading central banks to respond to those risks, see Chris Giles, "Bank of England's Andy Haldane warns over inflation in parting shot," Financial Times (June 30, 2021) (quoting warnings by Andrew Haldane that "people and companies had developed a 'dependency culture around cheap money' and that the potential for greater inflation was 'rising fast'"), https://www.ft.com/content/b664c3a0-7b59-48a6-83ef-3a4fe5f2f9ea; Michael Hirsh, "Are We in a Rerun of 'That 70s Show'? Some economists warn inflation is a ticking time bomb," Foreign Policy (July 23, 2021), https://foreignpolicy.com/2021/07/23/economists-warn-inflation-70s-biden-nixon/; James Politi et al., "Transatlantic inflation surge fuels economists' fears of overheating," Financial Times (July 15, 2021), https://www.ft.com/content/61346c2f-de96-4ad7-91c1-028efe4706ff; Ben White, "New concern for Biden: Could Larry Summers be right about inflation?", Politico (July 13, 2021), https://www.politico.com/news/2021/07/13/larry-summers-biden-inflation-499502. 
very likely to increase social inequality, as they inflict the greatest harm on wage earners,

recipients of fixed pensions, and lower- and middle-class households. ${ }^{115}$

An even greater potential danger is that escalating private and public debts could cause another systemic debt crisis comparable to 2008 and 2020, but with even worse results. During severe financial crises, as shown by Europe's experiences during the Great Depression and Great Recession, heavily indebted governments often lack sufficient credibility to borrow the funds needed to stabilize their financial systems. In that event, private-sector financial crises rapidly become sovereign debt crises, and governments have to choose between defaulting on their debts explicitly (through debt repudiations, moratoria, or restructuring) or implicitly (through currency devaluations or rapid inflation). The Eurozone barely avoided such a disastrous outcome during the Great Recession. ${ }^{116}$ In view of the colossal debt burdens that governments and central banks now carry, it is far from clear whether the next major debt crisis would have an equally benign conclusion. ${ }^{117}$

\section{Conclusion}

The pandemic financial crisis confirms that policymakers have failed to address the root causes of the global financial crisis of 2007-09. The global doom loop remains in place, as

\footnotetext{
1152021 BIS-AEO, supra note 17, at 44-54; Dirk Krueger, Kurt Mitman \& Fabrizio Perri, "On the Distribution of the Welfare Losses of Large Recessions" (National Bureau of Economic Research Working Paper 22458, July 2016), https://www.nber.org/papers/w22458.

${ }^{116}$ Bordo \& Siklos, supra note 113; Reinhart \& Sbrancia, supra note 107, at 4-5, 8, 12-15, 40-41; Tooze, supra note 7, Chapters 14-17; Wilmarth, Taming the Megabanks, supra note 1, at 97-103, 295-98.

${ }^{117}$ Gillian Tett, "Three questions from the Nixon era for Joe Biden," Financial Times (July 28, 2021) (stating that "total global debt is now more than three times the size of the global economy, [and] sooner or later ... this will probably cause a direct or indirect restructuring or a social or financial implosion"), https://www.ft.com/content/bb2bd452-727f-4fe4-877c-4d0875c187d3. The Congressional Budget Office recently warned that a continuing rise in the federal government's debt burden "would increase the risk of a fiscal crisisthat is, a situation in which investors lose confidence in the U.S. government's ability to service and repay its debt, causing interest rates to increase abruptly, inflation to spiral upward, or other disruptions, ... such as ... an erosion of confidence in the U.S. dollar as an international reserve currency, and more difficulty in financing public and private activity in international markets." Congressional Budget Office, The 2021 Long-Term Budget Outlook (Mar. 2021), at 10-13 (quote at 10), https://www.cbo.gov/system/files/2021-03/56977-LTBO-2021.pdf.
} 
universal banks and shadow banks continue to take speculative risks and to underwrite escalating levels of private and public debts in reliance on explicit and implicit support from governments and central banks. Our fragile, risky, and unstable financial system collapsed in 2008 and became paralyzed in 2020 , forcing governments and central banks to arrange huge bailouts. Those bailouts "bankified" global financial markets by expanding government safety nets to encompass short-term wholesale credit markets, systemically important shadow banks, and (in 2020) a wide array of business firms. Both bailouts also imposed enormous financial burdens on governments and central banks, raising serious questions about their ability to cope with the next systemic crisis.

Our failure-prone financial system is unsustainable and must be fundamentally reformed. As Minneapolis Fed President Neel Kashkari observed in September 2020, "what kind of absurd financial system do we have that requires the central bank to bail it out every decade? ... Is betting on successful future bailouts a sensible risk for [investors]? I would argue the answer is a resounding no." $" 118$

In my recent book, I proposed a series of reforms that would end the global doom loop and create a more stable, resilient, and competitive financial system. The most significant reform would be a new Glass-Steagall Act, which would separate banks from the capital markets and prohibit nonbanks from issuing functional substitutes for bank deposits. Another very important reform would require banks to fund a much higher percentage of their operations with equity capital instead of debt. ${ }^{119}$

\footnotetext{
${ }^{118}$ Neel Kashkari, "Capital Markets and Financial Regulation," Speech to the Conference of Institutional Investors (Sept. 18, 2020), https://www.minneapolisfed.org/speeches/2020/capital-markets-and-banking-regulation.

${ }_{119}$ Wilmarth, Taming the Megabanks, supra note 1, at 335-56. For further analysis of the need for much higher levels of bank equity capital, see Anat Admati \& Martin Hellwig, The Bankers' New Clothes: What's Wrong about Banking and What to Do about It (Princeton University Press, 2013); Federal Reserve Bank of Minneapolis, The Minneapolis Plan to End Too Big to Fail (Dec. 2017), https://www.minneapolisfed.org/policy/endingtbtf/finalproposal.
} 
A new Glass-Steagall Act would break up universal banks and shadow banks, thereby ending their toxic conflicts of interest, excessive risk-taking, and dangerous influence over regulators and politicians. It would create strong structural risk buffers and greatly reduce the probability that financial disruptions would spread across the newly-separated sectors of banking, insurance, and capital markets. It would permit governments and central banks to ensure the stability of the commercial banking system without being forced to provide openended guarantees and bailouts for the entire financial system. A new Glass-Steagall Act would discourage excessive growth in private debts during economic expansions and avoid the need for huge increases in government debts to finance massive bailouts during economic downturns. It would therefore provide the most direct and practical approach for ending the global doom loop and stopping the destructive boom-and-bust cycles of the past quarter century. ${ }^{120}$

We should also endeavor to reduce private-sector debts by repealing tax laws that encourage debt financing by business firms. For example, we should eliminate the tax code's current deduction for interest paid on corporate debt, thereby providing equal tax treatment for interest paid to debtholders and dividends paid to stockholders. We should also end the "carried interest tax advantage," which encourages leveraged buyouts by allowing private equity managers to pay taxes on their earnings at low capital gains rates instead of higher personal income rates. ${ }^{121}$ Removing artificial tax advantages for debt financing would encourage business firms to fund a larger percentage of their operations with equity capital, thereby producing a stronger and more resilient business sector.

${ }^{120}$ Wilmarth, Taming the Megabanks, supra note 1, at 335-56.

${ }^{121}$ Admati \& Hellwig, supra note 119, Chapter 9; McLean, supra note 85; see also Miriam Gottfried \& Juliet Chung, "Private Equity Firms and Hedge Funds, Facing a New Tax Burden, Prepare Their Defense," Wall Street Journal (April 28, 2021) (describing President Biden's proposal to "end the carried interest tax advantage," and discussing a private equity trade association's claim that the proposal would significantly reduce the number of buyouts by private equity firms), https://www.wsj.com/articles/private-equity-and-hedge-funds-facing-a-new-taxburden-prepare-their-defense-11619649070. 